\title{
Evaluation of soil intervention values in mine tailings in northern Chile
}

Elizabeth Lam Esquenazi ${ }^{\text {Corresp., }}{ }^{1}$ ， Brian Keith Norambuena ${ }^{2}$, Ítalo Montofré Bacigalupo ${ }^{3}$, María Gálvez Estay ${ }^{1}$

${ }^{1}$ Chemical Engineering Department, Universidad Católica del Norte, Antofagasta, Chile

2 Department of Computing \& Systems Engineering, Universidad Católica del Norte, Antofagasta, Chile

3 Metallurgical and Mining Department, Universidad Católica del Norte, Antofagasta, Chile

Corresponding Author: Elizabeth Lam Esquenazi

Email address: elam@ucn.cl

The aim of this work is to show a methodological proposal for the analysis of soil intervention values in mine tailings in order to determine the intervention requirements in the commune of Andacollo in northern Chile. The purpose of this analysis is to guide the intervention policies of both private and public organizations. The evaluation method is based on the Dutch legislation. The usability of the proposed methods depends on the available geochemical data from soil samples, in particular, we tackle the case when information regarding clay percentage in the soil is not available. We use the concepts of a threshold factor and an adjusted threshold factor to calculate a weighted intervention ranking. In order to illustrate the utility of this methodological proposal, a case study is carried out with the prescribed approach. In particular, this work presents an analysis of the elements of environmental significance related to the mining activity $(\mathrm{Hg}, \mathrm{Cd}, \mathrm{Pb}, \mathrm{As}$, $\mathrm{Cu}, \mathrm{Ni}, \mathrm{Zn}, \mathrm{Cr}$ ) in the Commune of Andacollo, Coquimbo Region, Chile. The analyzed samples are used to determine where the intervention of tailing deposits is necessary and where a solution to these environmental liabilities is required as soon as possible. Out of the 81 samples evaluated, it was found that 18 require a potential intervention, and of these samples, 7 of them are associated with abandoned tailings that, in some cases, are located close to the town center itself, 1 sample is associated with active tailings and the other 10 with inactive tailings. 


\section{Evaluation of soil intervention values in mine tailings in 2 northern Chile}

3 Elizabeth Lam Esquenazi ${ }^{1}$, Brian Keith Norambuena ${ }^{2}$, Ítalo Montofré Bacigalupo ${ }^{3}$, María Gálvez Estay ${ }^{1}$

$4{ }^{1}$ Chemical Engineering Department, Universidad Católica del Norte, Antofagasta, Antofagasta, Chile

52 Department of Computing \& Systems Engineering, Universidad Católica del Norte, Antofagasta,

6 Antofagasta, Chile

$7 \quad{ }^{3}$ Metallurgical and Mining Department, Universidad Católica del Norte, Antofagasta, Antofagasta, Chile

8

9 Corresponding Author:

10 Elizabeth Lam Esquenazi ${ }^{1}$

11 Av. Angamos 0610, Antofagasta, Antofagasta, 1270709, Chile.

12 Email address: elam@ucn.cl 
34 The aim of this work is to show a methodological proposal for the analysis of soil intervention values in mine tailings in order to determine the intervention requirements in the commune of Andacollo in northern Chile. The purpose of this analysis is to guide the intervention policies of both private and public organizations. The evaluation method is based on the Dutch legislation. The usability of the proposed methods depends on the available geochemical data from soil samples, in particular, we tackle the case when information regarding clay percentage in the soil is not available. We use the concepts of a threshold factor and an adjusted threshold factor to calculate a weighted intervention ranking. In order to illustrate the utility of this methodological proposal, a case study is carried out with the prescribed approach. In particular, this work presents an analysis of the elements of environmental significance related to the mining activity $(\mathrm{Hg}, \mathrm{Cd}$, $\mathrm{Pb}, \mathrm{As}, \mathrm{Cu}, \mathrm{Ni}, \mathrm{Zn}, \mathrm{Cr}$ ) in the Commune of Andacollo, Coquimbo Region, Chile. The analyzed samples are used to determine where the intervention of tailing deposits is necessary and where a solution to these environmental liabilities is required as soon as possible. Out of the 81 samples evaluated, it was found that 18 require a potential intervention, and of these samples, 7 of them are associated with abandoned tailings that, in some cases, are located close to the town center itself, 1 sample is associated with active tailings and the other 10 with inactive tailings.

\section{Introduction}

52

53 The Rio de Janeiro Summit of 1992 marked a historic milestone in the international commitment to protecting the environment (Sequeiros, 1998). In this summit, the importance of soils was recognized, as well as the need to protect them and their potential uses in the context of sustainable development, in particular against the contamination caused by activities of anthropogenic origin. This has led to the development of soil quality indicators with the purpose of preserving and improving the productivity of soils (Doran \& Parkin, 1996; Azapagic, 2014; Andrews et al., 2006; Römbke et al., 2016; de Graaf et al., 2017; Turpin et al., 2017).

In Chile, as in many parts of the world, there is a great number of mining environmental liabilities, mainly composed of tailings, which are potential risk sources for people and the environment. The great number of tailings distributed throughout Chile, many of which are abandoned with no one 
63 in charge of them, is a big problem for the State of Chile since the application of control measures

64

65

66

67

68 requires large amounts of money. Therefore, it is imperative to have an effective and economical tool that allows determining whether a tailing requires intervention or not.

Mining is Chile's main economic activity and the fundamental pillar of its growth. Thanks to the great geological diversity of its territory, large-scale deposits of different minerals can be found in the country. In the case of copper, Chile has one of the largest reserves worldwide (Oyarzún \& Oyarzún, 2011), being the leading country in the production of this resource. The national production of copper, which is concentrated mainly in the northern part of the country, reached $5,764,000$ tons of fine copper in 2015 and is expected to grow at an annual rate of $1.19 \%$ by 2020 (COCHILCO, 2016).

An important point to consider is the strong increase in the production of copper concentrates that is projected to rise by $32.1 \%$ within the next ten years, to the detriment of the production of cathodes due to the depletion of oxidized resources and the lack of new hydrometallurgical projects (Cifuentes, 2016). The strong growth of the production of concentrates, added to the low grades of ores, has affected the generation of tailings from concentrator plants. For 10 years (2002-2011) over 2,150 million tons of tailings have been produced that are generally not being treated. In addition, the average generation of tailings by 2020 is projected to amount to more than 380 million tons per year (Muñoz, 2017). Additionally, mining causes significant impact on the environment such as air pollution associated with the movement of land in the case of open-pit mining and emissions of toxic gases in smelters. Regarding water resources, this industry brings about their depletion and pollution due to discharges of industrial liquid waste to superficial channels, or by infiltration from tailings to underground layers. Also, ecosystems are affected by the mobilization of leached metals from tailings deposits. In addition, there may be a potential archaeological impact and an impact on the flora and fauna of the area.

Chile is a country that historically, besides copper, has focused on the mining of iron, gold, silver, lithium, iodine and potassium, without giving space to the exploitation of new raw materials such as cobalt, antimony, niobium and rare earth metals that have acquired increasingly important roles 
93 in modern industry and whose future supply has become a concern for the industrialized countries 94 given the dominance of China in the market for these elements.

95

96

In the case of Chile, copper production schemes have considered the recovery of secondary elements such as gold, silver, and molybdenum. However, the rest of the elements remain as part of the waste, such as tailings, gravel or slag. On the other hand, there are the environmental problems associated with mining tailings in Chile, totaling 696 deposits until 2016, of which 84\% correspond to non-active or abandoned tailings. Of the 584 non-active and abandoned tailings deposits, 310 do not have an environmental rating resolution available for its project and 477 do not have a closure plan because, due to their age, they have been closed and abandoned before the change in regulations (SERNAGEOMIN, 2016). Added to the unknown state of regularization of these tailings, an important growth of these deposits that would result in $81 \%$ more mass of tailings is expected, according to the projections of COCHILCO (2016). This is explained by the growing production of copper concentrates and the low-grade ores being exploited.

Despite the advances of the international community in this matter, Chile still has a pending debt due to the lack of regulations for soil quality. This is particularly harmful to the population due to the development of mining activities that bring about a series of negative impacts on the soil in several regions of the country. These mining liabilities have been the result of a historical mining that had very weak regulations regarding the closure stage. Fortunately, the Law 20,551 was promulgated in 2012, which demands that all mining sites present a closure plan prior to starting the mining project (SERNAGEOMIN, 2011; Neira, 2012).

In a mine site, the mineral of interest constitutes only a small fraction of the mined material (Wills \& Finch, 2015), because of this the mining process generates large volumes of waste, originating a great amount of tailings and mine waste in general, which contain a high variety of heavy metals and diversity of concentration levels (Burges et al., 2015; Pourret et al., 2016; Lam et al., 2016; Lam et al., 2017). This renders many hectares of soil unsuitable for agriculture and generates highly contaminated soils, in which substances will move depending on the physicochemical properties of the substrate and on the climate conditions of the area in which the deposit is located 
123 (Alloway., 2013; Chadwick et al., 2013; Li et al., 2014; Pandey et al., 2016; Antoniadis et al., 124 2017).

125

126 Closing a mine using low technology and without having an adequate plan that would enable to 127 ensure the health and safety of the people and the environment brings about socio-environmental, 128 financial and economic liabilities, affecting mainly communities close to where the mining sites 129 are or have been, or where processes associated with extraction and processing of minerals are 130 carried out, including electric generation, mineral transportation, and waste disposal, among others 131 (González et al., 2014; Marnika et al., 2015; Ettler et al., 2016; Lechner et al., 2016; Schoenberger, 132 2016; Espinoza et al., 2017; García et al., 2017).

134 Abandoned and/or paralyzed mining sites that are distributed throughout the country constitute potential sources of air, water and soil pollution; as well as potential harm to the population's environment and health (Li et al., 2014; Diami et al., 2016; Mickus \& Camacho, 2016; Pareja-

137 Carrera et al., 2014; Carkovic et al., 2016; Obiora et al., 2016; Antoniadis et al., 2017; Ghorbani \& Kuan, 2017; Christou et al., 2017; Espinoza \& Morris, 2017; Unger, 2017). It is imperative to face these issues, this requires identifying the potentially contaminated sites, the concentration, and variability of contaminants present in them, and also identifying the potential "victims" of these liabilities. In addition, it is necessary to consider the availability of technological and financial resources to address this new challenge generated by a mining industry that did not have the vision of a sustainable development, developing overexploitation and damage of resources, applying poor management practices and inadequate technology (Oyarzún, \& Oyarzún, 2011; Lam et al., 2016; Christou et al., 2017; Espinoza \& Morris, 2017; Unger, 2017).

The first regulations for estimating the degree of soil contamination were created in the Netherlands (Boekhold, 2008). This legislation provides procedures and standards for the shortterm sanitation of contaminated soils. The law established limits depending on several factors: the nature and concentration of the contaminants and the conditions of the place where the contaminants are (e.g. soil characteristics). 
153 In Chile, there have been several episodes of environmental impact on the marine environment 154 due to the presence of mine tailings deposits which hamper port activities, generate 155 geomorphological modifications on the coast and affect coastal ecosystems and recreational 156 activities (Castilla \& Nealler, 1978; Castilla, 1983; Salamanca et al., 2004; Ramírez et al., 2005; 157 Besaury et al., 2013; Valladares et al., 2013; Dold, 2014; Contreras-Porcia et al., 2017; Monsalve 158 et al., 2017). It is necessary to give a solution to these liabilities as soon as possible, for they have 159 generated chronic problems for the population, posing an even more serious threat to future 160 generations.

161

162

163

164

165

166

167

168

169

170

171

172

173

174

175

176

177

178

179

180

181

182

183

Given the above, it would be very useful to have a tool that allowed evaluating whether a tailing requires intervention or not. The aim of this study is to develop a methodology, based on the Dutch regulations, that allows classifying the tailings according to their intervention requirements as: 1) It does not require intervention 2) It requires intervention 3) Intervention is conditional on the availability of more information.

The methodology developed can be applied by means of a graphical method, which is used in case of having data on metal concentration and soil composition (in terms of its percentage of clay), or through a method based on conditional and unconditional threshold values (intervention thresholds) that only requires knowing the data of metal concentration in the soil. This allows applying the method even in situations where all the information required is not available. The methodology has been designed in such a way that future updates of the Dutch regulations are easily applicable.

A methodology as the one presented here will allow estimating if it is necessary to apply an intervention on the tailings found throughout Chile, as well as prioritizing those that require a more urgent intervention. Having a tool as the one presented in this work is vital for all those sites where there are tailings and the soil quality regulations are weak, or worse still, non-existent. It is important to note that the Dutch legislation, thanks to its rigorous foundation, is applied in Chile by the National Service of Geology and Mining, SERNAGEOMIN, as well as in other countries (Milenkovic et al., 2005; Swartjes et al., 2012). 


\section{Materials and methods}

\subsection{Methodological proposal}

186 The proposal is based on the Dutch legislation for the regulation of soil quality. In particular, this

187 law provides intervention values for different metals. The intervention values are threshold 188 concentrations above which it is considered that the soil presents a serious case of contamination. 189 Above the intervention values, the functionality of the soil for human, animal or plant life is 190 seriously affected or complicated. In particular, the 2013 revised version of the Dutch standard 191 (Dutch Soil Remediation Circular, 2013) will be used for the base values.

192

193 The selection of this regulation was based on the following aspects: 1) Dutch legislation provides 194

212

$213 S \operatorname{SIV}=\operatorname{SSIV} \cdot \frac{A+B \cdot x_{A}+C \cdot x_{M}}{A+25 \cdot B+10 \cdot C}$
(Eq. 1) 
214 Where each term of the equation is defined as follows:

215

216

217

218

219

220

221

222

223

224

225

226

227

228

229

230

231

232

233

234

235

236

237

238

239

240
- SSIV corresponds to the Standard Soils Intervention Value. SSIV is a value defined for a soil with $10 \%$ organic matter and $25 \%$ clay for each element. Table 1 presents the values for each element.

- Constants $A, B$ and $\mathrm{C}$ correspond to parameters based on the characteristics of each element. Table 1 presents the values of these constants for some relevant metals.

- The variable $x_{A}$ corresponds to the percentage of clay in the substrate that is being evaluated, expressed as a number between 0 and 100. In case that the clay content is less than a $2 \%$ then $x_{A}$ is assigned the value 2 (that is, the lowest value it can take is $2 \%$ ).

- The variable $x_{M}$ corresponds to the percentage of organic matter in the substrate that is being evaluated, expressed as a number between 0 and 100. In case that the content of organic matter is less than a $2 \%$ then $x_{M}$ is assigned the value 2 (that is, the lowest value it can take is $2 \%$ ).

In the methodology proposed, two assumptions are made:

1. It is assumed that the data have been previously gathered, that the mineral concentration in the soil is available and, optionally, the percentage of clay in the soil.

2. It is assumed that the tailings do not have organic matter, or its percentage is equal to or less than $2 \%$.

In case that both the concentration of metal in the soil and the percentage of clay are available, a graphical method can be directly applied to evaluate the necessity of intervention in a soil. On the contrary, if the clay percentage is not available, the methodology proposed allows using conditional and unconditional intervention thresholds defined in this work to determine the intervention requirements and prioritize the sites.

On the other hand, it must be mentioned that the proposal in this work can be generalized, since, although the methodology proposed has been developed for soils containing mine tailings, a similar strategy could be applied for soils of similar characteristics or that accept assumptions of similar nature. 


\section{D.2 Intervention values and graphical method}

242 The lowest value that each percentage $x_{A}$ and $x_{M}$ can be assigned is 2 . In particular, the

243 composition of tailing deposits guarantees that the percentage of organic matter is negligible (i.e.

244 close to 0), thus, according to the conditions of the method, it is assumed that for all the soils

245 considered in this work $x_{M}=2$.

246

247 Bearing in mind all previous observations, in this work a referential table of the intervention values

248 has been built. These are presented in Table 2. Soil intervention values (SIV) have been calculated

249 using the method provided by the Dutch guidelines under the supposition that the organic matter

250 percentage in a tailing is negligible $(\leq 2 \%)$. If the concentration in $\mathrm{mg} / \mathrm{kg}$ exceeds the values

251 indicated in this table for the composition of a given soil, then the tailings deposit must be

252 intervened.

253

254 In case that the clay percentage in the soil is not found in Table 2, a linear interpolation can be

255 used to obtain the result. This will produce the correct result (because the base calculation model

256 is linear). In case the clay percentage is less than $2 \%$, it must be assumed that it takes the value of

$2572 \%$ (in accordance with the Dutch guidelines), so it must not be extrapolated.

258

259

260

261

262

263

264

265

266

267

268

269

270

271

The results of Table 2 are graphically represented for Arsenic in Figure 1 as an example. The clay percentage is on the abscissa axis and the concentration of the corresponding element in $\mathrm{mg} \mathrm{kg}^{-1}$ is on the ordinate axis. These graphs show the straight line determined by the formula of intervention value for tailings (intervention threshold). Two zones can be observed in the graph: the zone above the intervention threshold that indicates the necessity of intervention and the zone below that represents the safe zone that does not require immediate intervention.

It should be noted that the intervention threshold is given by a line of positive slope, this suggests that for a given a value of the element concentration, then all the clay percentages above a certain threshold will not require an intervention (i.e. they will be in the safe zone). The threshold for this can be found graphically by tracing a horizontal line at the given concentration and finding the point where it intersects with the intervention threshold inside the 0 to 100 range of clay percentage. However, it is important to note that for some values of the concentration there will 
272 be no intersection, in fact, if the horizontal line lies above the intervention threshold line, then it is

273 always necessary to intervene. On the other hand, if the horizontal line is below the intervention

274 threshold line it will always be in the safe zone. These observations provide the motivation for the

275 definition of the Threshold Factor and Adjusted Threshold Factor in the next sections, which can

276 be seen as a simpler quantitative alternative to the graphical methods.

277

\subsection{Threshold factor}

279 This work defines the concept of Threshold Factor $C_{F}$, corresponding to the minimum percentage 280 of clay acceptable in function of the concentration of the element measured (according to the 281 parameters of the Dutch standard). If the real percentage of clay in the soil exceeds this value, then

282 the intervention of the soil will not be required. In case the clay percentage is lower than the 283 threshold factor then the soil will require intervention.

285 The threshold factor is obtained by setting $x_{M}=2$ (because it is assumed that the organic matter 286 content is negligible) and solving the SIV equation for $x_{A}$. From this procedure, the following 287 equation is obtained:

$C_{F}=\frac{S I V}{S S I V} \cdot\left(\frac{A+25 \cdot B+10 \cdot C}{B}\right)-\frac{(A+2 C)}{B}$

290

Note that although this formula can deliver values lower than 0 or higher than 100 , these have no sense physically. In fact, these values are utilized as limits to determine if the tailings deposit does not require intervention or if the intervention is strictly necessary, regardless of the real percentage of clay in the soil. The threshold factor $C_{F}$ facilitates the analysis of the tailings deposits by the considerations shown in Table 3.

Thus, it is recommended that samples are obtained to evaluate the clay percentage of the soils in 298 the tailings deposits that have a threshold factor between 0 and 100 (conditional intervention). 


\subsection{Adjusted Threshold Factor}

302 It should be noted that the threshold factor in its original definition brings about problems of scale 303 when converting the results obtained with real values into a graph. In order to simplify the 304 graphical analysis of the results, the Adjusted Threshold Factor $\left(A C_{F}\right)$ is proposed in Equation 3. 305 This minimizes the problems of scale and facilitates interpretation.

306

307

$A C_{F}=\operatorname{sign}\left(C_{F}\right) \cdot \log \left(1+\operatorname{abs}\left(C_{F}\right)\right)$

308

It should be noted that this is similar to a logarithmic scale, but it admits negative values. The 310 evaluation by means of $A C_{F}$ is carried out as follows:

- If $A C_{F} \leq 0$ then it is not necessary to intervene (it corresponds to the cases where $C_{F} \leq 0$ ).

- If $A C_{F} \geq 2$ then it is necessary to intervene (it corresponds to the cases where $C_{F} \geq 100$ ). It must be noted that $A C_{F}=2.004$ when $C_{F}=100$, but for practical purposes the difference

These cases are summarized in Table 4 which can be seen as the adjusted version of Table 3 .

Based on a similar reasoning to the Unlikely Conditional Intervention case, high values of the adjusted conditional factor (i.e. close to 2) could probably be taken as sites with a high probability 
330

331

332

333

334

335

336

337

338

339

340

341

342

343

344

345

346

347

348

349

350

351

352

353

354

355

356

357

358

359

recommendation is more of a heuristic to reduce the extra resources that would be needed to take another sample to determine the real clay percentage. This is especially important if there are more sites in a conditional intervention state than available resources for sampling. In light of this, the value of $\varepsilon$ should be chosen carefully.

\subsection{Andacollo mine tailings in Chile}

According to the survey carried out in December 2016 by the National Service of Geology and Mining (SERNAGEOMIN), in Chile there are 696 tailings deposits, catalogued as active (16,1\%), inactive $(62,6 \%)$ and abandoned $(21,3 \%)$, distributed from the Tarapacá region up to the Metropolitan region. (Tarapacá 1,00\%, Antofagasta 6,18\%, Atacama 22,27 \%, Coquimbo 52,87 $\%$, Valparaíso 10,49 \%, Bernardo O’Higgins 2,59\%, Maule 0,43\%, Aysén 0,72\% and Metropolitan region 3,45\%).

Of particular interest is the Coquimbo region for its great number of tailing deposits compared to the other regions of the country. The Coquimbo region has been an almost continuous exploited source of $\mathrm{Cu}, \mathrm{Au}$, and $\mathrm{Hg}$ in Chile for centuries. In spite of this, the communities living in this zone are still underdeveloped and suffer from the extended contamination produced by the inefficient treatment of mine tailings and wastes (Higueras et al. 2004). It must be noted that bioremediation plans exist for the commune, however, there is a number of problems, such as a lack of a regulatory legal framework and operational issues, which prevent their implementation (Leiva \& Morales, 2013).

This case study focuses on the Commune of Andacollo, in particular, the utilized data corresponds to the geochemical characterization of tailings deposits carried out by SERNAGEOMIN in the Commune of Andacollo in the Coquimbo Region, Chile. In particular, 81 samples have been analyzed corresponding to 22 tailings deposits. There have been previous studies to assess the contamination and risks in the commune of Andacollo, such as Higueras et al. 2004 where a general environmental analysis was carried out, detecting significant contamination of the surrounding landscape due to decades of inefficient treatment of waste-rock stockpiles and flotation tailings. 
360 The present work focuses on the elements considered critical for the environment, presenting the 361 analysis carried out to the following elements of environmental relevance related to mining 362 activity: $\mathrm{Hg}, \mathrm{Cd}, \mathrm{Pb}, \mathrm{As}, \mathrm{Cu}, \mathrm{Ni}, \mathrm{Zn}, \mathrm{Cr}$. Andacollo is located in the Coquimbo region of Chile and 363 is about $57 \mathrm{~km}$ to the southeast of La Serena. It is situated at latitude $30^{\circ} 12^{\prime} 00^{\prime \prime}$ south and longitude $36471^{\circ} 05^{\prime} 00^{\prime \prime}$ east. It covers an area of about $310 \mathrm{~km}^{2}$ and is bounded on the south by Ovalle, northeast 365 by the Commune of Vicuña, and southeast by the Commune of Río Hurtado and, west by the 366 Commune of Coquimbo, and north by the Commune of La Serena. It is also home to several 367 mining activities (Higueras et al., 2004).

368

To use the graphical method described in Section 2.2 it is necessary to have data about the percentage of clay and the concentration of the element of interest. Using this information, the sample must be located in the corresponding graph to see in which zone it lies. However, since this method requires the value of clay percentage, it is not possible to apply it directly to the data provided by SERNAGEOMIN. Thus, the threshold values approach is used for this data set. The results obtained for the different elements studied are presented and discussed. Specifically, the state of each tailing is analyzed based on the criterion defined by the threshold factor.

The results obtained for the different elements studied are presented and discussed. The samples have been identified following the identification number of the tailing deposit and its origin that can be from the tailings pond (TP), the sediments (S) or the wall (W). The concentration values reported as lower than a certain number $n$ (in $\mathrm{mg} / \mathrm{kg}$ ) were assigned the value $n \mathrm{mg} / \mathrm{kg}$ to obtain an estimate corresponding to the worst case. Subsequently, the same scheme is applied if the data have that format. Specifically, the state of each tailing is analyzed based on the criterion defined by the threshold factor.

\section{B. Results}

\subsection{Arsenic}

The results obtained for each sample available in the SERNAGEOMIN data are summarized in Table 5. It is noted that for most samples, arsenic levels are low enough to guarantee that intervention is not necessary at the moment. On the other hand, there are four samples that suggest 
391 an unconditional intervention, regardless of the percentage of clay in the soil, while there is only 392 one sample that indicates a conditional need of intervention in a tailings deposit. Only in the latter 393 case, it would be necessary to obtain the real value of the clay percentage of the soil. It must be 394 noted that the elements that are shown in pairs with similar values come from the same deposit, 395 but from different samples, due to which they exhibit a similar behavior. This same pattern is 396 repeated in the subsequent analyses.

397

In particular, the samples 191-W, 191-W-2, 190-TP, and 190-TP-2 require unconditional 399 intervention. These samples are associated with the ARIZONA 1 and ARIZONA 2 tailing deposits. 400 Sample 152-TP suggests that the deposit SANTA TERESITA 2 requires conditional intervention. 401

408.2.

\section{Cadmium}

403

404

405

406

407 408

409

410.3.

The threshold factors obtained for each sample are shown in Figure 2. The results obtained for each sample available in the SERNAGEOMIN data are summarized in Table 5. In this case, it should be noted that none of the samples suggests an unconditional intervention. Nevertheless, a considerable number of samples suggests a conditional intervention, due to which it is important to determine the corresponding percentage of clay to evaluate the course of actions needed in those deposits.

412 413 


\subsection{Nickel}

423 The threshold factors obtained for each sample are shown in Figure 3. The results obtained for 424 each sample available in the SERNAGEOMIN data are summarized in Table 5. The particular 425 case of Nickel is different from the previous ones since none of the extreme values observed above 426 are present here. For this criterion, all the tailings are classified as requiring conditional 427 intervention, due to which it is necessary to determine the percentage of clay to decide whether 428 there should be intervention or not.

429

430.5. Mercury

431 The threshold factors obtained for each sample are shown in Figure 4. The results obtained for 432 each sample available in the SERNAGEOMIN data are summarized in Table 5. Regarding the 433 results obtained for Mercury, it is necessary to note that a great majority is below intervention 434 values, due to which in the short term it is not necessary to carry out interventions on them. 435 Nevertheless, there is a sample that indicates the need for unconditional intervention 436 (corresponding to an abandoned deposit) and some that indicate conditional intervention with the 437 available data.

438

\subsection{Copper}

440 The threshold factors obtained for each sample are shown in Figure 5. The results obtained for 441 each sample available in the SERNAGEOMIN data are summarized in Table 5. The analysis of 442 the data shows the necessity of intervention of the tailings deposits regarding copper concentration. 443 There is only one sample that indicates that intervention is not needed, and it corresponds to an 444 abandoned deposit, all the other cases require intervention to some degree, be it conditional or 445 unconditional.

446

44B.7. Zinc

448 The results obtained for each sample available in the SERNAGEOMIN data are summarized in 449 Table 5. In this case, there are no samples that suggest an unconditional intervention. There are 450 five samples that indicate that conditional intervention is required, which correspond mainly to 451 inactive deposits. The other samples correspond in its majority to deposits that do not require 
452 intervention. Regarding the five that require conditional intervention, it is necessary to obtain the

453 real values of the percentage of clay to define whether intervention is needed.

454

455 In particular, the samples 191-W, 191-W-2, 190-TP, 190-TP-2, and 154-S require conditional 456 intervention. These samples are associated with the ARIZONA 1, ARIZONA 2 and SANTA 457 TERESITA 2 tailing deposits.

458

\subsection{Chromium}

460 The threshold factors obtained for each sample are shown in Figure 6. The results obtained for 461 each sample available in the SERNAGEOMIN data are summarized in Table 5. For Chromium, it 462 can be observed that there are six samples of inactive deposits that indicate the necessity of 463 unconditional intervention. Most samples suggest only a conditional intervention, while the rest 464 would not require intervention in the short term.

465

466. Discussion

467

\subsection{General evaluation}

469 Out of the 696 deposits surveyed by SERNAGEOMIN (2016), 368 are found in the Coquimbo region, distributed in 13 communes, one of them being the commune of Andacollo, which concentrates the highest number of tailing deposits in the region. According to the survey by SERNAGEOMIN (2016), out of the 368 deposits in the region, 118 are found in the commune of Andacollo, which are then classified according to their status as abandoned (35), active (8) and

474 inactive (75).

475

4769 tailing deposits are found in urban areas in the commune of Andacollo, which were abandoned

477 in the 1950's. That is to say, they have coexisted with the population for 70 years, constituting a 478 potential risk for them and the environment. Given the high costs associated with the required 479 interventions, it is necessary to rank the tailings to intervene according to priority. The information 480 regarding the current tonnage of the tailings is scarce, however, the information available 481 corresponds to the tonnages of tailings authorized for each deposit, which fluctuate between 482500,000 and $416,000,000$ tons. 
484 The deposits that constitute major problems correspond to those that are abandoned, since they do

485

486

487

488

489

490

491

492

493

494

495

496

497

498

499

500

501

502

503

504

505

506

507.2

508

509

510

511

512

513 not have a responsible organization or person to take charge of them, being the State of Chile the one that must have the necessary resources to face this great challenge. The authorized values for the abandoned tailings in the commune of Andacollo are between 500 and 227,850 tons.

Having carried out the corresponding analysis for each element, the summary of results obtained for each tailings deposit status (Active, Inactive and Abandoned) is shown. Table 6 presents a summary of the results obtained for each sample of the SERNAGEOMIN data for active and inactive deposits. It should be noted that in almost all cases of active deposits it is necessary to carry out an unconditional intervention in each deposit due to copper concentrations. If the particular case of copper is not considered, conditional intervention is required in all tailings. It should be noted that in almost all cases an unconditional intervention in the deposit is needed due to copper concentrations, although in contrast to the previous case, there are also cases that show a potentially problematic concentration of chromium or arsenic. At any rate, if the particular case of copper is not considered, conditional intervention is required in all tailings.

Table 7 shows a summary of results obtained for each sample of the SERNAGEOMIN data for abandoned deposits. It should be noted that in almost all cases it is necessary to carry out an unconditional intervention in each deposit due to the high concentrations of copper. If the particular case of copper which requires unconditional intervention in all tailings is not considered, it can be observed that, although the reasons for conditional intervention might be different in each case, the element nickel in all cases suggests a conditional intervention.

\section{Weighted Intervention Ranking}

The results show that in the vast majority of the tailings it is necessary to carry out an intervention due to the high concentration of copper. Although there is a great variability between the Adjusted Threshold Factors for the different deposits, the fact that the vast majority of them are above the unconditional intervention limit makes prioritization difficult, even if they were ordered by $A C_{F}$ results. Given this situation, copper concentration in each tailing and their respective Adjusted 
514 Threshold Factor is not a good indicator to provide a prioritization to interventions, due to which

515 it is necessary to be guided by the results of the other elements in this case.

516

517 According to the above, it can be seen that for all the other elements analyzed $(\mathrm{Cd}, \mathrm{Pb}, \mathrm{Zn}, \mathrm{Cr}, \mathrm{As}$,

$518 \mathrm{Ni}$ and $\mathrm{Hg}$ ) a significant number of the evaluated sites are in the category of conditional 519 intervention or unconditional intervention. A simple alternative to prioritize the sites that require 520 an expeditious intervention is starting with the sites that have the highest number of elements that 521 require intervention (conditional or unconditional). Nevertheless, a method based on a linear 522 model of weighted costs according to the health and environmental risk represented by each 523 element is proposed.

525 For these reasons, this work proposes the use of a Weighted Intervention Ranking $\left(W I R_{j}\right)$ of the $526 j$-th site $(1 \leq j \leq m$, where $m$ is the number of sites of the study) and is defined according to 527 Equation 4.

$528 W I R_{j}=\sum_{i=1}^{n} w_{i} \cdot x_{i j}$

529 Where $n$ stands for the number of elements of interest in the analysis of the tailings (in the case of 530 this article $n=8), 1 \leq w_{i} \leq 5$ is an integer that represents the influence of the $i$-th element on the 531 WIR and $x_{i j}$ corresponds to the Adjusted Threshold Factor for the $i$-th element in the $j$-th site of 532 interest.

533

534 The definition of the weights can be controlled by the user of the methodology, who can assign 535 different values to the weights according to environmental, economic and legal criteria. In Table 5368 the weighting used in this work is shown. Note that the values can be modified according to the 537 needs of each analysis. Our values are based on the work of Adriano (2001), in particular, we use 538 the toxicity information for plants, animals, and humans through the following criteria: if a metal 539 is potentially toxic to plants, animals, and humans, it is given a weight of 3 ; if it is only toxic to 540 two of these three, then it is given a weight of 2 ; similarly, if it is only potentially toxic to one of 541 them, a score of 1 is given. Since it would not make sense to analyze the case of a zero-weight 542 metal in this study, the actual weights range from 1 to 3. 
544 According to the values provided in Table 8, Weighted Intervention Rankings can be obtained.

545 The results obtained for the six sites with the highest Weighted Intervention Rankings are shown

546 in Table 9. The average WIR for all sites is -4.53 , while the median is $-5,71$ and the standard

547 deviation is 7.53. The highest value of $W I R$ is 19.88 and the lowest value is -16.28 . Figure 7 shows

548 the distribution of the Weighted Intervention Rankings.

549

550 On the other hand, the difference between the fourth and the fifth sites of highest WIR in Table 9 551 should be noted. It should also be highlighted that the top four values are more than two standard 552 deviations above average. Considering the above, this point lends itself as a natural limit to define 553 a threshold regarding intervention priority, at least in a first stage.

554

555

Based on these results, it is estimated that the first priority of intervention corresponds to the 556 deposits ARIZONA 1 and ARIZONA 2, due to their high WIR value. In a subsequent stage, 557 SANTA TERESITA 2 and ARENILLAS 2 should be intervened. It is thus necessary to design an 558 intervention plan for these deposits. On the other hand, if we consider a value of zero WIR as the 559 cut-off for priority intervention, then 18 out of the $81(22.22 \%)$ samples suggest requirements of 560 intervention according to this metric.

561

562 The proposed methodology was applied on 81 samples of available geochemical data (22 tailings 563 deposits), obtaining that 18 samples indicate a critical intervention requirement (with 10 coming 564 from inactive deposits, 1 from an active deposit and 7 from abandoned deposits). Of these samples, 56511 come from tailings associated with $\mathrm{Cu}-\mathrm{Au}$ extraction processes and 7 come from tailings 566 associated with $\mathrm{Au}$ extraction processes. Of the corresponding tailings, the one with greater 567 tonnage corresponds to "Punta Caletones 4", which is in a state of abandonment with an admitted 568 capacity of 227,850 tons.

569 Of course, the exact intervention plan and their feasibility depend on an analysis of environmental 570 impact and economic and legal aspects out of the scope of this work, since the aim of the 571 methodology is to indicate the sites that should be prioritized according to the defined criteria. 572 Having shown the calculation and application of the WIR, the exposition of the evaluation 573 methodology proposed in this work is concluded. 
575 As a further analysis of our results, we perform a one-way ANOVA with the different deposit 576 states (Active, Inactive and Abandoned) as the main factor. Our null hypothesis is that the state of 577 the deposit has no influence on the WIR values, while our alternative hypothesis is that the state 578 of the deposit does have an effect on the WIR values. Our results indicate that there is a significant 579 difference between the value of the WIR depending on the state of the deposit ( $p$-value $=0.005)$. 580 In particular, Tukey's test suggests that there are no significant differences between Active and 581 Abandoned deposits ( $\mathrm{p}$-value $>0.10$ ), but Inactive deposits are different, showing a higher mean 582 WIR than Active ( $\mathrm{p}$-value $=0.045)$ and Abandoned deposits ( $\mathrm{p}$-value $=0.006)$.

583

\subsection{Analysis of results}

585 Out of the abandoned tailings in the commune of Andacollo, 9 of them are located inside the urban 586 area, in daily coexistence with the population, constituting a potential risk to the health of people

587 (Morales, 2013). These are found in the open and can be destabilized both physically and 588 chemically, as a result of the interaction with external factors. For example, it is known that Chile 589 is a highly seismic country, which means that in the face of a large-scale earthquake, houses and 590 road structures could collapse and be wiped out, causing the death of people. This occurred in 591 Concepción (Chile) during the 2010 earthquake, as liquefied mine tailings hit a farmer's house, 592 burying people alive under the tailing mass (Verdugo et al., 2010).

593

594 On the other hand, the interaction of sulphide with air and rainfall generates acid mine drainage, 595 which tends to have a great impact on ecosystems, water resources and soils (Kefeni et al., 2017).

596 The lost spaces occupied by these tailings should also be taken into account because they cannot 597 be used for other activities such as agriculture, residential development, or others. 598

599 Since the tailings in Andacollo are located in the heart of the city, the handling of the toxic metal 600 for any type of intervention becomes very difficult and dangerous, so it requires a special 601 treatment. However, there are not many precedents on how to perform this task, since in general, 602 the tailings are in remote places of the communities. 
604 The following two aspects must be taken into account when performing tailings intervention. On 605 the one hand, the potential environmental impact, which puts people and the environment at risk; 606 and on the other, an economic one, since current technology was not available when they were 607 exploited, it is possible that they contain high-grade ore according to current standards; this 608 represents a potential for the recovery of metals with a commercial interest.

609

610 When we speak of intervention, we refer to it as an action that avoids the direct contact of the 611 tailings with people, with water systems (surface and groundwater) or with ecosystems. The main 612 objective of the measures is to stabilize the tailings, both physically and chemically, in order to 613 protect the health and safety of people and the environment.

614

615 Finally, it is important to point out that although the methodology applied allows ranking the 616 tailings of Andacollo, this would be the first phase in the tailings' assessment, which would allow 617 assigning intervention priorities. The results should be corroborated with a risk assessment, which 618 should consider the size of the tailings, the proximity to potentially impacted receptors (human 619 and ecological receptors) and any other factor considered important.

According to the obtained results, of the 81 samples evaluated, it was found that 18 require a 622 potential intervention, of these samples 7 are associated to abandoned tailings, 1 to active tailings and 10 to inactive tailings. While the assets and liabilities belong to the responsible companies that according to the new Chilean legislation (Law 20,551 on mine closure plans) must take charge of them, ensuring physical and chemical stability in perpetuity, this does not occur with abandoned tailings, on which it is urgent to carry out a more thorough study that allows prioritizing the intervention requirements. The accepted tonnages of the critical abandoned tailings found in this work fluctuate between 5,872 and 227,850 tons. For the purposes of a subsequent study, these data are of great importance, either to solve the problem with compounds of environmental connotation or to recover metals of commercial interest.

631

632 In an international context, this work complements the Dutch regulations, exhaustively detailing 633 the definition and application of the method. In addition, an example of its application is given in 634 an area considered critical in the Chilean national environment. The latter is especially important 
635 because Chile does not have specialized regulations and the availability of experimental data is 636 deficient, so this methodology is highly appropriate for this context. Given the above, this proposal 637 could be applied in countries with similar conditions, that is, countries that do not have specialized 638 national regulations or high availability of the required data.

639

640 At a global level, there are many tailings that are abandoned, many of these are historical tailings 641 and therefore there is a lack of information regarding their characterization. Since some of these 642 tailings might occupy high volumes in addition to their high heterogeneity, their characterization 643 involves high costs and could require extensive financing. Furthermore, given their age, no 644 organization or person can be held responsible for them, as occurs with the abandoned tailings in 645 Chile. Thus, it is the state that must take charge of the situation, but this requires adequate 646 financing. The high costs render the amount of interventions required unfeasible, so it is highly 647 necessary to have a cost-effective tool to rank these tailings, which in turn will lead to 648 prioritization. Based on this, characterizations can be made with an appropriate sampling design, 649 in order to perform the corresponding risk assessment.

650

\section{Conclusions}

652

653 This article has exposed a detailed methodology to analyze the requirements of soil intervention. 654 This methodology is based on the stringent and thoroughly tested Dutch regulation for soil 655 remediation (2013 version). The main contribution of this work is the definition of the conditional 656 and unconditional intervention thresholds and the simple graphical method. A case study in the 657 Commune of Andacollo in Chile has been detailed, the methodology has been applied successfully, 658 revealing several sites that require both unconditional and conditional intervention.

659

660 For the threshold values used by this methodology, the classic intervention value formula provided 661 by the Dutch normative has been modified and adapted to provide a simpler calculation approach 662 for mine tailings, where it can safely be assumed that organic matter is negligible. This approach 663 can be adapted to other kinds of soil provided that a similar assumption can be made about their 664 characterization. In particular, the values and formulas provided in this article can be applied to 665 any soil where organic matter can be assumed to be insignificant. Finally, the results obtained in 
666 the case study indicate the necessity of intervention of the tailings. Unconditional interventions 667 being more severe and requiring a more immediate attention. On the other hand, conditional 668 intervention might not be necessary depending on the clay percentage of the soil. Thus, for these 669 tailings, a more detailed analysis is required.

670

671 One of the potential limitations of the proposed methodology and the performed analysis is that 672 the Andacollo background soil values have not been explicitly considered. Adding this information 673 could improve the accuracy of the results. On the other hand, in the case of samples associated 674 with a conditional intervention, it would also be necessary to have the clay percentage in order to 675 obtain a more accurate estimate. However, in the case of unconditional intervention, the 676 methodology would not need this information. Nevertheless, as an initial estimate of the potential 677 environmental risk of these tailings, the methodology delivers appropriate results.

678

679 If the deposit concentration delivers an Adjusted Threshold Value greater than zero and lower than 680 the threshold value for unconditional intervention, then it could be considered as slightly 681 contaminated (requiring conditional intervention). If it exceeds the threshold value, it will be 682 necessary to proceed with an intervention strategy. However, this intervention must be carried out 683 case by case, in particular, this analysis must consider all the metals present in the deposit, and this 684 is why the calculation of the WIR is important since it allows assigning weights to the importance 685 of each element with respect to its associated risks. The results obtained with this methodology are 686 only the first step to guide the study. The final decision on an intervention, if it is required, will 687 depend on the evaluation of the risks and environmental conditions of the site.

688

\section{References}

690 1. Adriano, D. C. (2001). Trace elements in terrestrial environments: Biogeochemistry, 691 bioavailability, and risks of metals, 2 nd.

692 2. Andrews, S. S., Karlen, D. L., \& Cambardella, C. A. (2004). The soil management assessment 693 framework. Soil Science Society of America Journal, 68(6), 1945-1962.

694 695

3. Alloway, B. J. (2013). Sources of heavy metals and metalloids in soils. In Heavy metals in soils (pp. 11-50). Springer Netherlands. 
696 4. Antoniadis, V., Shaheen, S. M., Boersch, J., Frohne, T., Du Laing, G., \& Rinklebe, J. (2017).

697 Bioavailability and risk assessment of potentially toxic elements in garden edible vegetables 698 and soils around a highly contaminated former mining area in Germany. Journal of 699 environmental management, 186, 192-200.

700 5. Azapagic, A. (2004). Developing a framework for sustainable development indicators for the 701

702

703

704

705

706

707

708

709

710

711

712

713

714

715

716

717

718

719

720

721

722

723

724

725

726 mining and minerals industry. Journal of cleaner production, 12(6), 639-662.

6. Besaury, L., Marty, F., Buquet, S., Mesnage, V., Muyzer, G., \& Quillet, L. (2013). Culturedependent and independent studies of microbial diversity in highly copper-contaminated Chilean marine sediments. Microbial ecology, 65(2), 311-324.

7. Bempah, C. K., \& Ewusi, A. (2016). Heavy metals contamination and human health risk assessment around Obuasi gold mine in Ghana. Environmental monitoring and assessment, $188(5), 261$.

8. Boekhold, A. E. (2008). Ecological risk assessment in legislation on contaminated soil in The Netherlands. Science of the total environment, 406(3), 518-522.

9. Burges, A., Epelde, L., \& Garbisu, C. (2015). Impact of repeated single-metal and multi-metal pollution events on soil quality. Chemosphere, 120, 8-15.

10. Carkovic, A. B., Calcagni, M. S., Vega, A. S., Coquery, M., Moya, P. M., Bonilla, C. A., \& Pastén, P. A. (2016). Active and legacy mining in an arid urban environment: challenges and perspectives for Copiapó, Northern Chile. Environmental geochemistry and health, 38(4), 1001-1014.

11. Castilla, J. C., \& Nealler, E. (1978). Marine environmental impact due to mining activities of El Salvador copper mine, Chile. Marine Pollution Bulletin, 9(3), 67-70.

12. Castilla, J. C. (1983). Environmental impact in sandy beaches of copper mine tailings at Chañaral, Chile. Marine pollution bulletin, 14(12), 459-464.

13. Cifuentes, C. (2016). Proyección de la producción de cobre en Chile 2016 - 2027 (N²72.131). Recuperado de https://www.COCHILCO.cl/Mercado.

14. COCHILCO (2016). "Anuario Estadístico de la Minería". Comisión chilena del cobre. Santiago. Chile.

15. Chadwick, M. J., Highton, N. H., \& Lindman, N. (Eds.). (2013). Environmental Impacts of Coal Mining \& Utilization: A Complete Revision of Environmental Implications of Expanded Coal Utilization. Elsevier. 
727

728

729

730

731

732

733

734

735

736

737

738

739

740

741

742

743

744

745

746

747

748

749

750

751

752

753

754

755

16. Christou, A., Theologides, C. P., Costa, C., Kalavrouziotis, I. K., \& Varnavas, S. P. (2017). Assessment of toxic heavy metals concentrations in soils and wild and cultivated plant species in Limni abandoned copper mining site, Cyprus. Journal of Geochemical Exploration, 178, $16-22$.

17. Contreras-Porcia, L., Meynard, A., López-Cristoffanini, C., Latorre, N., \& Kumar, M. (2017). Marine Metal Pollution and Effects on Seaweed Species. In Systems Biology of Marine Ecosystems (pp. 35-48). Springer, Cham.

18. Geochemical data from tailing deposits in Chile, October 2017. http://sitiohistorico.sernageomin.cl/mineria-relaves.php.

19. Darko, G., Dodd, M., Nkansah, M. A., Ansah, E., \& Aduse-Poku, Y. (2017). Distribution and bioaccessibility of metals in urban soils of Kumasi, Ghana. Environmental Monitoring and Assessment, 189(6), 260.

20. De Graaf, K. J., Platjouw, F. M., \& Tolsma, H. D. (2017). The future Dutch Environment and Planning Act in light of the ecosystem approach. Ecosystem Services.

21. Diami, S. M., Kusin, F. M., \& Madzin, Z. (2016). Potential ecological and human health risks of heavy metals in surface soils associated with iron ore mining in Pahang, Malaysia. Environmental Science and Pollution Research, 23(20), 21086-21097.

22. Dold, B. (2014). Submarine tailings disposal (STD). A review. Minerals, 4(3), 642-666.

23. Doran, J. W., \& Parkin, T. B. (1996). Quantitative indicators of soil quality: a minimum data set. Methods for assessing soil quality/editors, John W. Doran and Alice J. Jones; editorial committee, Richard P. Dick...[et al.]; editor-in-chief SSSA, Jerry M. Bigham; managing editor, David M. Kral; associate editor, Marian K. Viney.

24. Dutch Soil Remediation Circular (July, 2013), Ministry of Infrastructure and the Environment, Netherlands. Retrieved on 10/05/2017, available from: http://rwsenvironment.eu/subjects/soil/legislation-and/soil-remediation/.

25. Espinoza, R. D., \& Morris, J. W. (2017). Towards sustainable mining (part II): Accounting for mine reclamation and post reclamation care liabilities. Resources Policy, 52, 29-38.

26. Ettler, V., Quantin, C., \& Kersten, M. (2016). Applied Geochemistry special issue on Environmental impacts of mining and smelting. Applied Geochemistry, 64, 64-1. 
756

757

758

759

760

761

762

763

764

765

766

767

768

769

770

771

772

773

774

775

776

777

778

779

780

781

782

783

784

785

786

27. Garcia, L. C., Ribeiro, D. B., Oliveira Roque, F., Ochoa-Quintero, J. M., \& Laurance, W. F. (2017). Brazil's worst mining disaster: corporations must be compelled to pay the actual environmental costs. Ecological applications, 27(1), 5-9.

28. Ghorbani, Y., \& Kuan, S. H. (2017). A review of sustainable development in the Chilean mining sector: past, present and future. International Journal of Mining, Reclamation and Environment, 31(2), 137-165.

29. González, S. A., Stotz, W., \& Lancellotti, D. (2014). Effects of the discharge of iron ore tailings on subtidal rocky-bottom communities in northern Chile. Journal of Coastal Research, 30(3), 500-514.

30. Higueras, P., Oyarzun, R., Oyarzún, J., Maturana, H., Lillo, J., \& Morata, D. (2004). Environmental assessment of copper-gold-mercury mining in the Andacollo and Punitaqui districts, northern Chile. Applied Geochemistry, 19(11), 1855-1864.

31. Kefeni, K. K., Msagati, T. A., \& Mamba, B. B. (2017). Acid mine drainage: prevention, treatment options, and resource recovery: a review. Journal of cleaner production, 151, 475493.

32. Kelepertzis, E. (2014). Accumulation of heavy metals in agricultural soils of Mediterranean: insights from Argolida basin, Peloponnese, Greece. Geoderma, 221, 82-90.

33. Lam, E. J., Gálvez, M. E., Cánovas, M., Montofré, I. L., Rivero, D., \& Faz, A. (2016). Evaluation of metal mobility from copper mine tailings in northern Chile. Environmental Science and Pollution Research, 23(12), 11901-11915.

34. Lam, E. J., Cánovas, M., Gálvez, M. E., Montofré, Í. L., Keith, B. F., \& Faz, Á. (2017). Evaluation of the phytoremediation potential of native plants growing on a copper mine tailing in northern Chile. Journal of Geochemical Exploration, 182, 210-217.

35. Lechner, A. M., Kassulke, O., \& Unger, C. (2016). Spatial assessment of open cut coal mining progressive rehabilitation to support the monitoring of rehabilitation liabilities. Resources Policy, 50, 234-243.

36. Leiva, M. \& Morales, S. (2013). Environmental assessment of mercury pollution in urban tailings from gold mining. Ecotoxicology and environmental safety, 90, 167-173.

37. Li, Z., Ma, Z., van der Kuijp, T. J., Yuan, Z., \& Huang, L. (2014). A review of soil heavy metal pollution from mines in China: pollution and health risk assessment. Science of the Total Environment, 468, 843-853. 
787 788

789

790

791

792

793

794

795

796

797

798

799

800

801

802

803

804

805

806

807

808

809

810

811

812

813

814

815

816

817

38. Macklin, M. G., Brewer, P. A., Balteanu, D., Coulthard, T. J., Driga, B., Howard, A. J., \& Zaharia, S. (2003). The long-term fate and environmental significance of contaminant metals released by the January and March 2000 mining tailings dam failures in Maramureş County, upper Tisa Basin, Romania. Applied Geochemistry, 18(2), 241-257.

39. Marnika, E., Christodoulou, E., \& Xenidis, A. (2015). Sustainable development indicators for mining sites in protected areas: tool development, ranking and scoring of potential environmental impacts and assessment of management scenarios. Journal of Cleaner Production, 101, 59-70.

40. Mickus, K., \& Camacho, L. M. (2016). Abandoned PbZn mining wastes and their mobility as proxy to toxicity: A review. Science of the total environment.

41. Milenkovic, N., Damjanovic, M., \& Ristic, M. (2005). Study of Heavy Metal Pollution in Sediments from the Iron Gate (Danube River), Serbia and Montenegro. Polish Journal of Environmental Studies, 14(6).

42. Monsalve, S. M., Martínez, L., Vásquez, K. Y., Orellana, S. A., Vergara, J. K., Mateo, M. M., ... \& Lillo, D. D. C. (2017). Trace element contents in fine particulate matter (PM2. 5) in urban school microenvironments near a contaminated beach with mine tailings, Chañaral, Chile. Environmental Geochemistry and Health, 1-15.

43. Morales, S. (2013). Environmental assessment of mercury pollution in urban tailings from gold mining. Ecotoxicology and environmental safety, 90, 167-173.

44. Muñoz Aracena, G. (2017). Estudio del relave abandonado Anita, comuna de Tiltil y sus posibles implicancias a la comunidad (Doctoral dissertation, Universidad Andrés Bello).

45. Neira, S. P. (2012). Chile. Yearbook of International Environmental Law, 22(1), 372.

46. Obiora, S. C., Chukwu, A., \& Davies, T. C. (2016). Heavy metals and health risk assessment of arable soils and food crops around $\mathrm{Pb}-\mathrm{Zn}$ mining localities in Enyigba, southeastern Nigeria. Journal of African Earth Sciences, 116, 182-189.

47. Oyarzún, J., \& Oyarzún, R. (2011). Sustainable development threats, inter-sector conflicts and environmental policy requirements in the arid, mining rich, northern Chile territory. Sustainable Development, 19(4), 263-274.

48. Pandey, B., Agrawal, M., \& Singh, S. (2016). Ecological risk assessment of soil contamination by trace elements around coal mining area. Journal of soils and sediments, 16(1), 159-168. 
818 49. Pareja-Carrera, J., Mateo, R., \& Rodríguez-Estival, J. (2014). Lead (Pb) in sheep exposed to 819 mining pollution: Implications for animal and human health. Ecotoxicology and environmental 820 safety, 108, 210-216.

821 50. Pourret, O., Lange, B., Bonhoure, J., Colinet, G., Decrée, S., Mahy, G., ... \& Faucon, M. P. 822 (2016). Assessment of soil metal distribution and environmental impact of mining in Katanga 823 (Democratic Republic of Congo). Applied Geochemistry, 64, 43-55.

824 51. Ramírez, M., Massolo, S., Frache, R., \& Correa, J. A. (2005). Metal speciation and 825 environmental impact on sandy beaches due to El Salvador copper mine, Chile. Marine 826 Pollution Bulletin, 50(1), 62-72.

827 52. Römbke, J., Gardi, C., Creamer, R., \& Miko, L. (2016). Soil biodiversity data: Actual and 828 potential use in European and national legislation. Applied Soil Ecology, 97, 125-133.

829 53. Salamanca, M. A., Jara, B., \& Rodríguez, T. (2004). Niveles de Cu, Pb y Zn en agua y 830 Perumytilus purpuratus en bahía San Jorge, norte de Chile. Gayana (Concepción), 68(1), 53$831 \quad 62$.

832 54. Schoenberger, E. (2016). Environmentally sustainable mining: The case of tailings storage 833 facilities. Resources Policy, 49, 119-128.

55. SERNAGEOMIN (2016). Tailing deposit survey in Chile. December 2016. http://sitiohistorico.sernageomin.cl/mineria-relaves.php.

56. SERNAGEOMIN (2011) Environmental Management and Law closure.

57. Sequeiros, L. (1998). III Cumbre de la Tierra (Río de Janeiro, 1992) al fracaso de la Conferencia de Kioto (1997): Claves para comprender mejor los problemas ambientales del Planeta, De la. Enseñanza de las Ciencias de la Tierra, 6(1), 3-12.

58. Soil Protection Act (2013), Ministry of Infrastructure and the Environment, Netherlands. http://rwsenvironment.eu/subjects/soil/legislation-and/

59. Swartjes, F. A., Rutgers, M., Lijzen, J. P. A., Janssen, P. J. C. M., Otte, P. F., Wintersen, A., ... \& Posthuma, L. (2012). State of the art of contaminated site management in The Netherlands: Policy framework and risk assessment tools. Science of the Total Environment, 427, 1-10.

60. Turpin, N., ten Berge, H., Grignani, C., Guzmán, G., Vanderlinden, K., Steinmann, H. H., ... \& Laguna, A. (2017). An assessment of policies affecting Sustainable Soil Management in Europe and selected member states. Land Use Policy, 66, 241-249. 
849 61. Unger, C. (2017). Legacy Issues and Abandoned Mines. In Mining in the Asia-Pacific (pp. 850 333-369). Springer, Cham.

851 62. Valladares, F., Alvarado, S., Urra, R., Abarca, J., Inostroza, J., Codoceo, J., \& Ruz, M. (2013).

852 Cadmium and Lead content in Liver and Kidney tissues of Wild Turkey Vulture Cathartes aura 853 (Linneo, 1758) from Chañaral, Atacama desert, Chile.

854 63. Verdugo, R., Villalobos, F., Yasuda, S., Konagai, K., Sugano, T., Okamura, M., ... \& Torres, 855 A. (2010). Description and analysis of geotechnical aspects associated to the large 2010 Chile 856 earthquake. Obras y Proyectos, 8, 25-36.

857 64. Wills, B. A., \& Finch, J. (2015). Wills' mineral processing technology: an introduction to the 858 practical aspects of ore treatment and mineral recovery. Butterworth-Heinemann. 


\section{Figure 1}

Graphs of intervention regions for Arsenic source: own elaboration).

Each graph represents the intervention zones according to the parameters of each element.

The separating line corresponds with the intervention threshold.

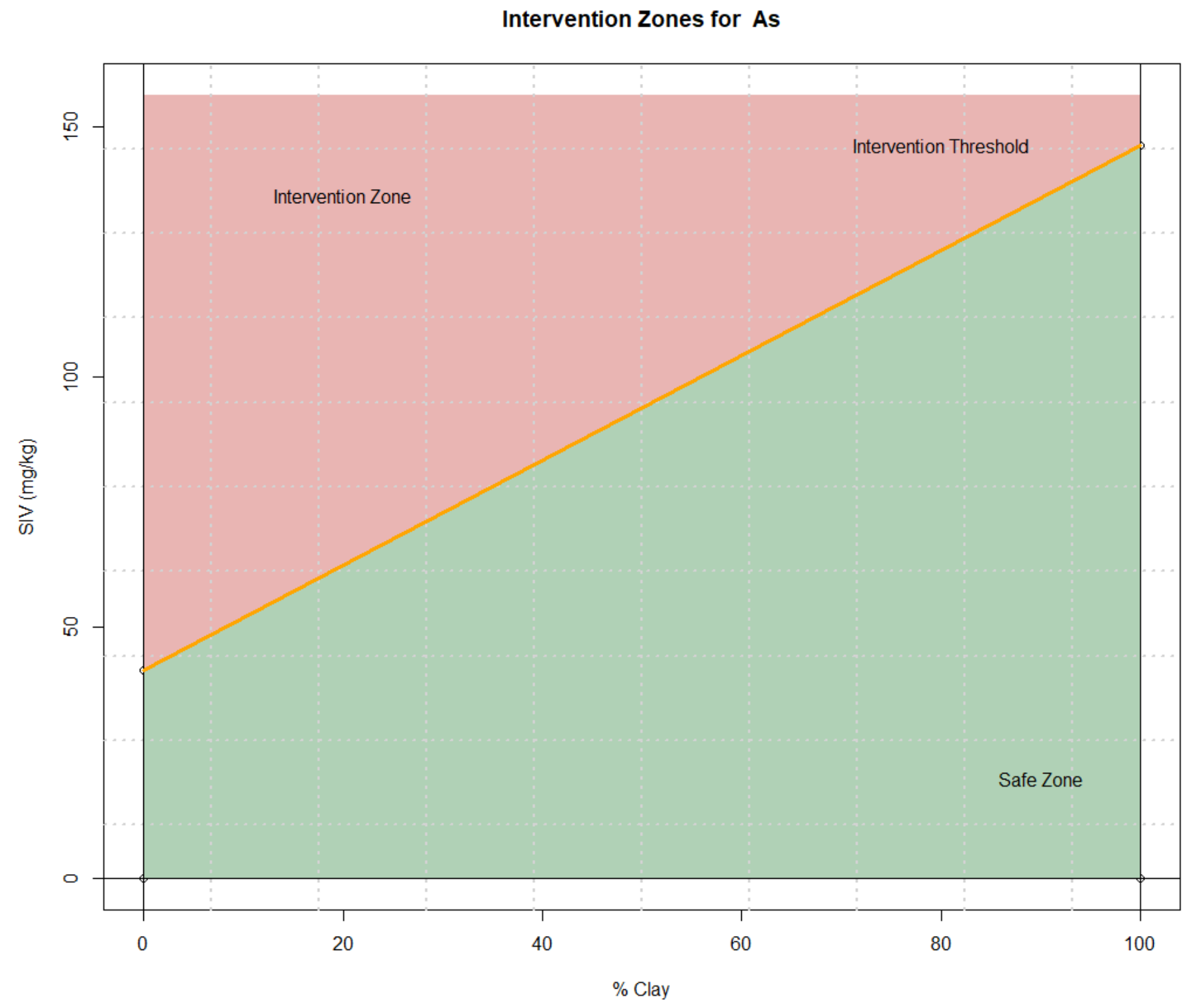




\section{Figure 2}

Adjusted threshold factor for Cadmium.

Each data point indicates the value of the Adjusted Threshold Factor of a tailing sample for Cadmium. The red line indicates the unconditional intervention threshold and the green line indicates the conditional intervention threshold. The data points between these lines are considered for a Conditional Intervention, while the points above the red line are considered for an Unconditional Intervention.

Adjusted Threshold Factor (Cd)

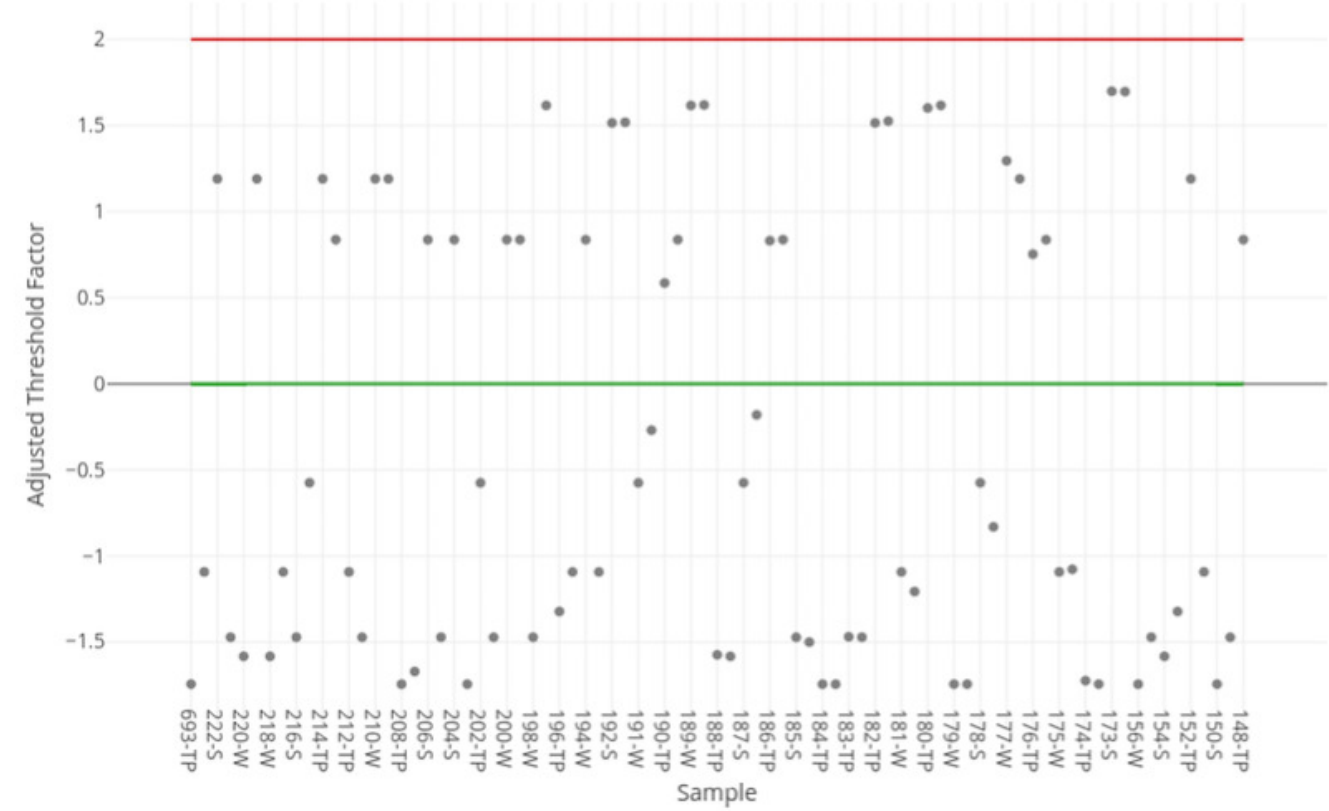




\section{Figure 3}

Adjusted threshold factor for Nickel.

Each data point indicates the value of the Adjusted Threshold Factor of a tailing sample for Nickel. The red line indicates the unconditional intervention threshold and the green line indicates the conditional intervention threshold. The data points between these lines are considered for a Conditional Intervention, while the points above the red line are considered for an Unconditional Intervention.

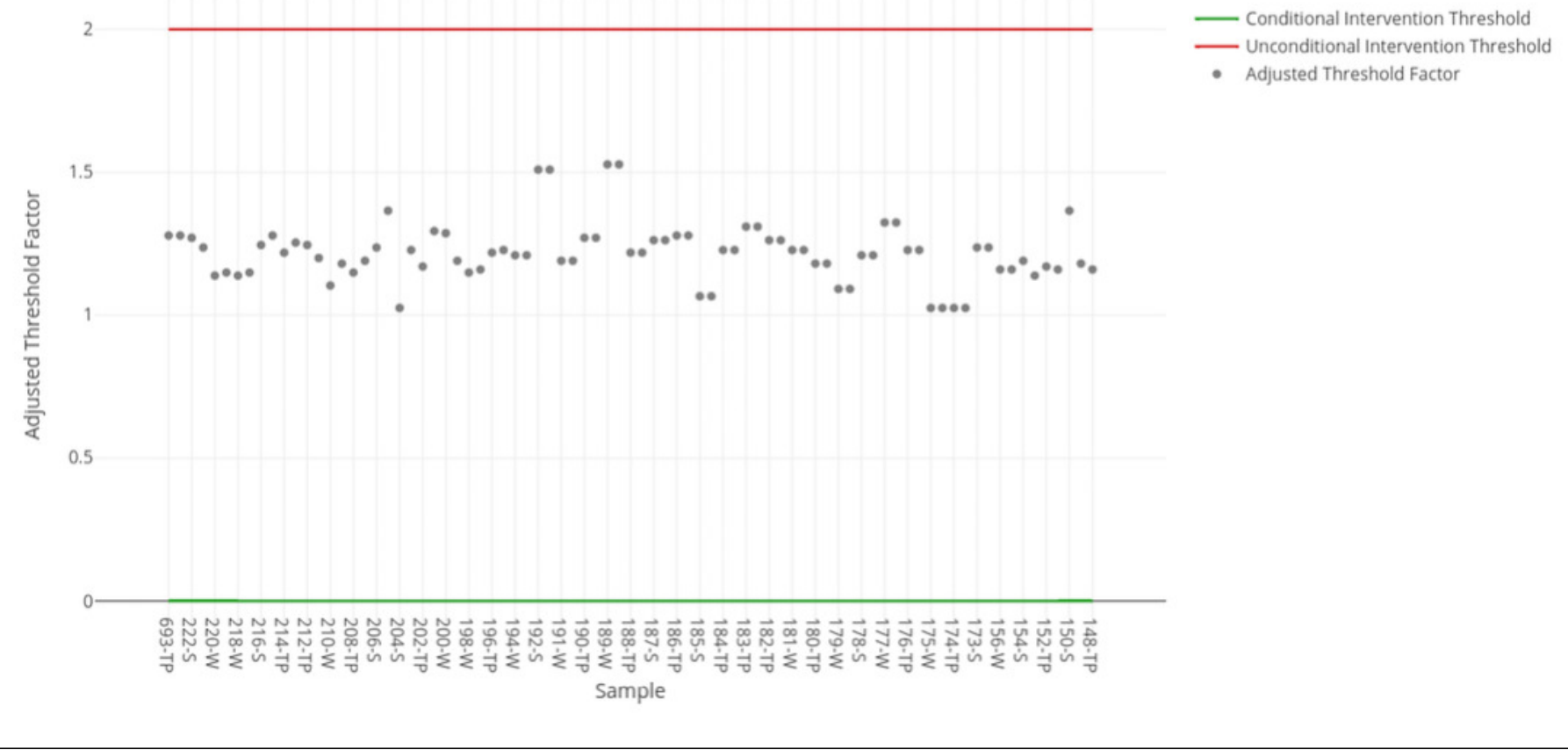




\section{Figure 4}

Adjusted threshold factor for Mercury.

Each data point indicates the value of the Adjusted Threshold Factor of a tailing sample for Mercury. The red line indicates the unconditional intervention threshold and the green line indicates the conditional intervention threshold. The data points between these lines are considered for a Conditional Intervention, while the points above the red line are considered for an Unconditional Intervention.

Adjusted Threshold Factor $(\mathrm{Hg})$

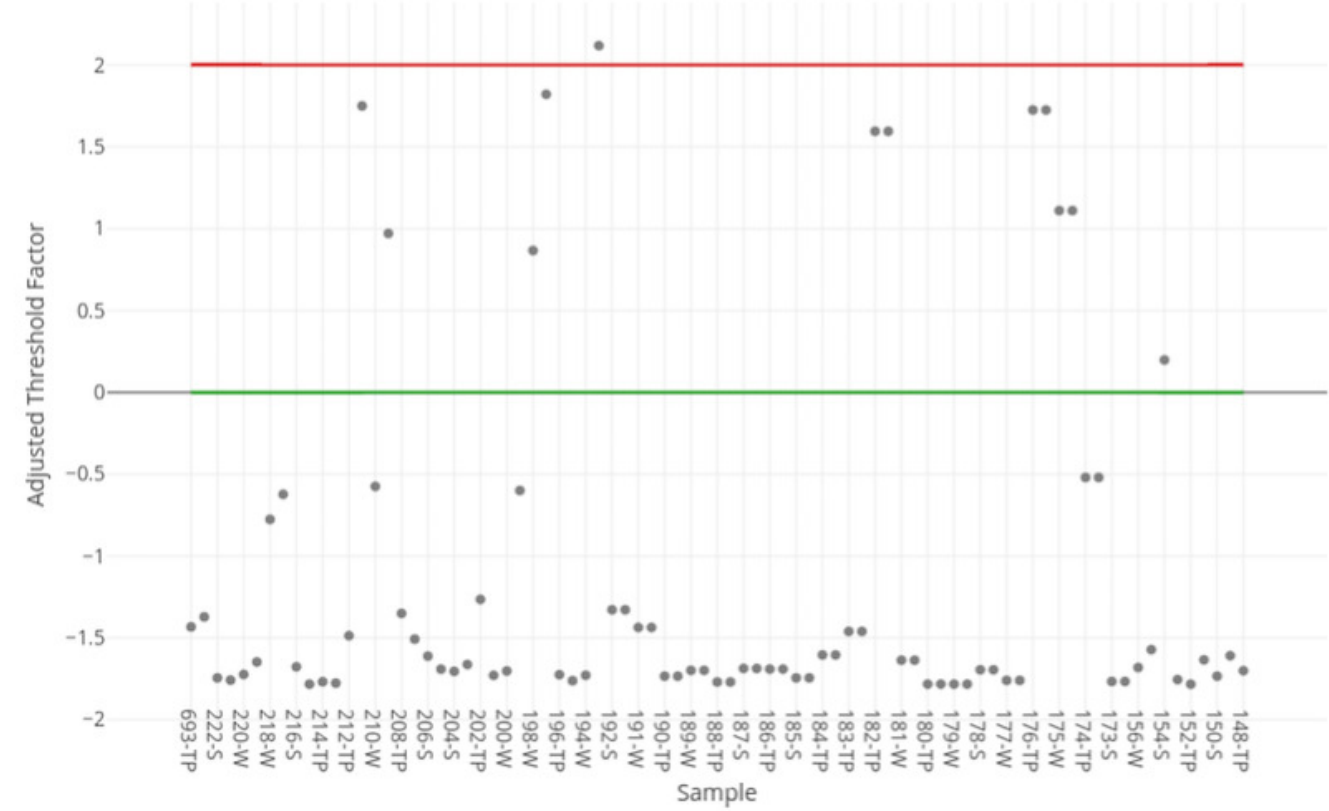




\section{Figure 5}

Adjusted threshold factor for Copper.

Each data point indicates the value of the Adjusted Threshold Factor of a tailing sample for Copper. The red line indicates the unconditional intervention threshold and the green line indicates the conditional intervention threshold. The data points between these lines are considered for a Conditional Intervention, while the points above the red line are considered for an Unconditional Intervention.

Adjusted Threshold Factor (Cu)

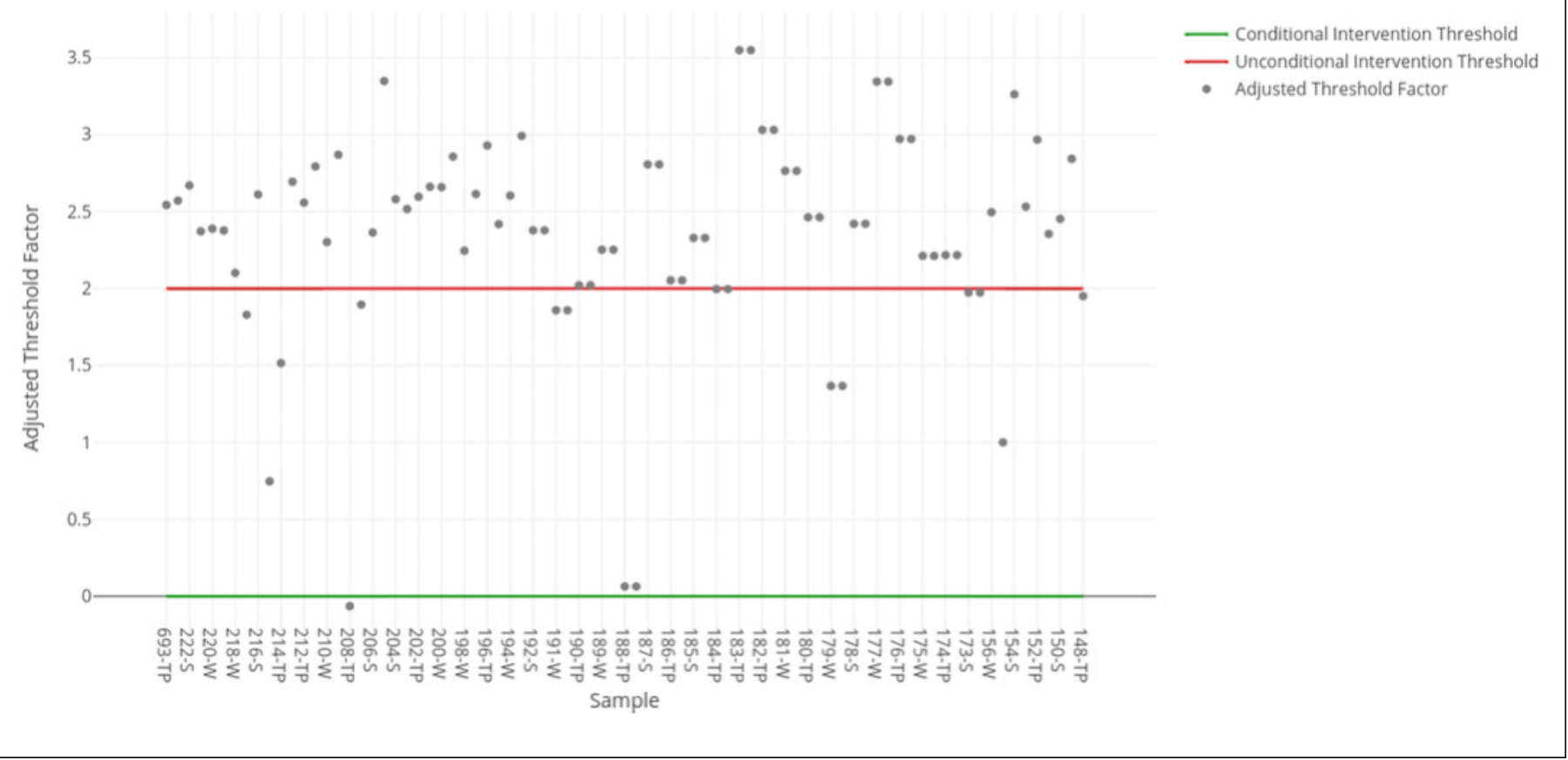




\section{Figure 6}

Adjusted threshold factor for Chromium.

Each data point indicates the value of the Adjusted Threshold Factor of a tailing sample for Chromium. The red line indicates the unconditional intervention threshold and the green line indicates the conditional intervention threshold. The data points between these lines are considered for a Conditional Intervention, while the points above the red line are considered for an Unconditional Intervention.

Adjusted Threshold Factor (Cr)

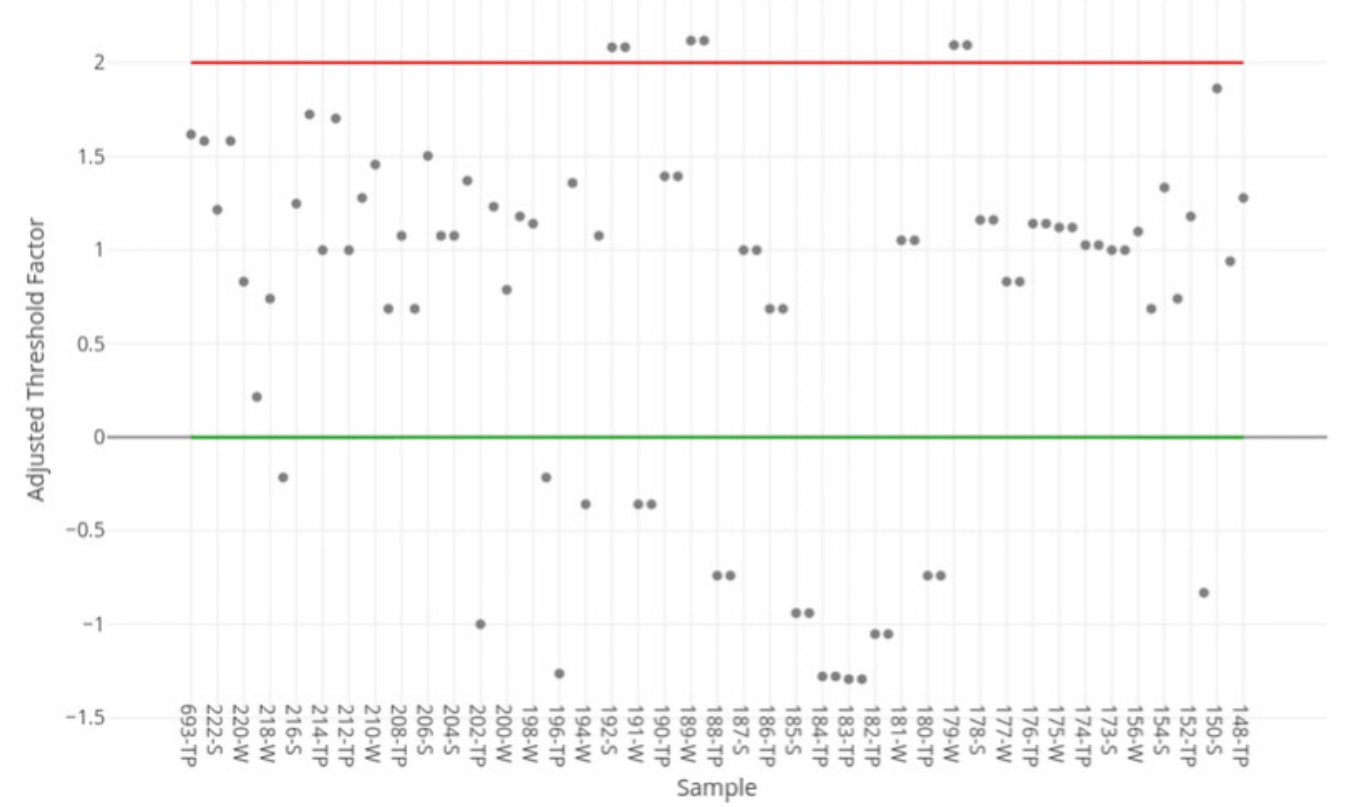

- Conditional Intervention Threshold 


\section{Figure 7}

Histogram for the values of Weighted Intervention Ranking for all the 81 samples from the Commune of Andacollo.

This graph shows the distribution of the Weighted Intervention Ranking (WIR) for all the samples from the Commune of Andacollo. The average WIR for all sites is -4.53 , while the median is $-5,71$ and the standard deviation is 7.53 . The highest value of WIR is 19.88 and the lowest value is -16.28 .

Weighted Intervention Ranking Histogram

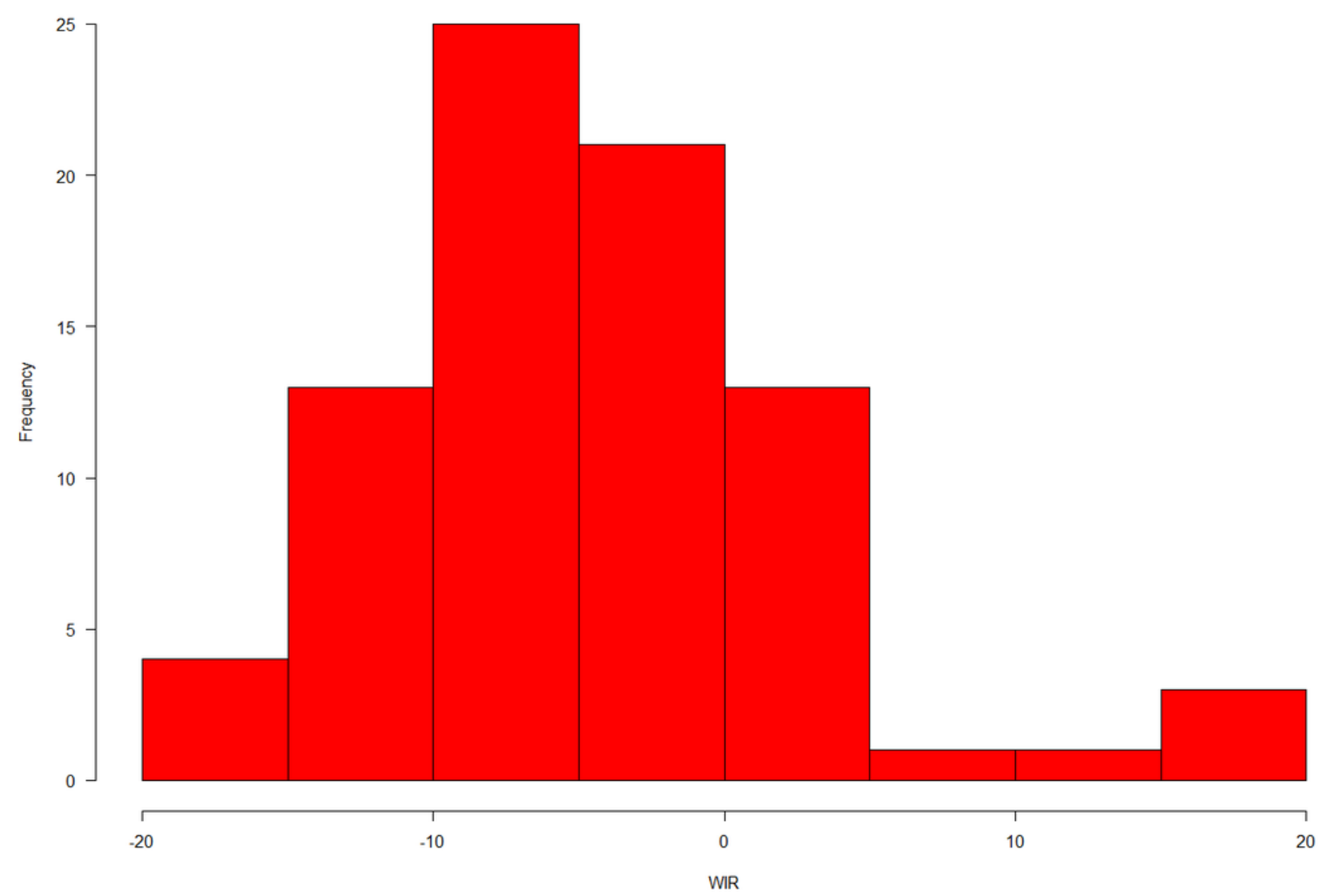




\section{Table $\mathbf{1}$ (on next page)}

Parameters of the equation for the calculation of SSIV for each element (source: Dutch soil quality regulations, 2013).

Each row shows the value of the corresponding parameter for each element. 
1 Table 1 - Parameters of the equation for the calculation of SSIV for each element (source: Dutch

2

\begin{tabular}{|c|c|c|c|c|}
\hline Element & A & B & C & SSIV (mg kg-1 \\
\hline Arsenic & 15 & 0.4 & 0.4 & 76 \\
\hline Cadmium & 0.4 & 0.007 & 0.021 & 13 \\
\hline Mercury & 0.2 & 0.0034 & 0.0017 & 4 \\
\hline Lead & 50 & 1 & 1 & 530 \\
\hline Nickel & 10 & 1 & 0 & 100 \\
\hline Zinc & 50 & 3 & 1.5 & 720 \\
\hline Copper & 15 & 0.6 & 0.6 & 190 \\
\hline Chromium & 50 & 2 & 0 & 78 \\
\hline
\end{tabular}




\section{Table 2 (on next page)}

Referential table of intervention values (SIV) of each element for different soils according to clay percentage assuming organic matter is $\leq 2 \%$ (source: own elaboration).

Each row of this table presents the intervention values (SIV) of each element, depending on the percentage of Clay in the soil and assuming a negligible amount of organic matter. 
1 Table 2 -Referential table of intervention values (SIV) of each element for different soils

2 according to clay percentage assuming organic matter is $\leq 2 \%$ (source: own elaboration).

\begin{tabular}{|c|c|c|c|c|c|c|c|c|c|}
\hline \multirow{2}{*}{\multicolumn{2}{|c|}{ SIV (mg/kg) }} & \multicolumn{8}{|c|}{ Element } \\
\hline & & As & $C d$ & $H g$ & $P b$ & $\mathrm{Ni}$ & $Z n$ & $C u$ & $\mathrm{Cr}$ \\
\hline \multirow{21}{*}{ 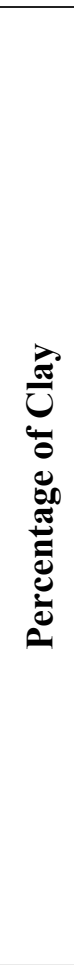 } & 2 & 43.50 & 7.55 & 2.78 & 336.71 & 34.29 & 303.43 & 91.83 & 42.12 \\
\hline & 5 & 46.65 & 7.90 & 2.92 & 355.41 & 42.86 & 349.71 & 101.33 & 46.80 \\
\hline & 10 & 51.89 & 8.48 & 3.14 & 386.59 & 57.14 & 426.86 & 117.17 & 54.60 \\
\hline & 15 & 57.13 & 9.06 & 3.37 & 417.76 & 71.43 & 504.00 & 133.00 & 62.40 \\
\hline & 20 & 62.37 & 9.64 & 3.59 & 448.94 & 85.71 & 581.14 & 148.83 & 70.20 \\
\hline & 25 & 67.61 & 10.22 & 3.82 & 480.12 & 100.00 & 658.29 & 164.67 & 78.00 \\
\hline & 30 & 72.86 & 10.80 & 4.05 & 511.29 & 114.29 & 735.43 & 180.50 & 85.80 \\
\hline & 35 & 78.10 & 11.38 & 4.27 & 542.47 & 128.57 & 812.57 & 196.33 & 93.60 \\
\hline & 40 & 83.34 & 11.96 & 4.50 & 573.65 & 142.86 & 889.71 & 212.17 & 101.40 \\
\hline & 45 & 88.58 & 12.54 & 4.72 & 604.82 & 157.14 & 966.86 & 228.00 & 109.20 \\
\hline & 50 & 93.82 & 13.12 & 4.95 & 636.00 & 171.43 & 1044.00 & 243.83 & 117.00 \\
\hline & 55 & 99.06 & 13.70 & 5.17 & 667.18 & 185.71 & 1121.14 & 259.67 & 124.80 \\
\hline & 60 & 104.30 & 14.28 & 5.40 & 698.35 & 200.00 & 1198.29 & 275.50 & 132.60 \\
\hline & 65 & 109.54 & 14.85 & 5.62 & 729.53 & 214.29 & 1275.43 & 291.33 & 140.40 \\
\hline & 70 & 114.79 & 15.43 & 5.85 & 760.71 & 228.57 & 1352.57 & 307.17 & 148.20 \\
\hline & 75 & 120.03 & 16.01 & 6.07 & 791.88 & 242.86 & 1429.71 & 323.00 & 156.00 \\
\hline & 80 & 125.27 & 16.59 & 6.30 & 823.06 & 257.14 & 1506.86 & 338.83 & 163.80 \\
\hline & 85 & 130.51 & 17.17 & 6.52 & 854.24 & 271.43 & 1584.00 & 354.67 & 171.60 \\
\hline & 90 & 135.75 & 17.75 & 6.75 & 885.41 & 285.71 & 1661.14 & 370.50 & 179.40 \\
\hline & 95 & 140.99 & 18.33 & 6.97 & 916.59 & 300.00 & 1738.29 & 386.33 & 187.20 \\
\hline & 100 & 146.23 & 18.91 & 7.19 & 947.77 & 314.29 & 1815.44 & 402.16 & 195 \\
\hline
\end{tabular}

3

4

5

6 


\section{Table 3(on next page)}

Summary of intervention cases with respect to the threshold factor.

Each row describes a different case depending on the value of the threshold factor. 
Table 1 -Summary of intervention cases with respect to the threshold factor.

\begin{tabular}{|c|c|c|c|c|c|}
\hline Case & Condition & Description & $\begin{array}{l}\text { Required } \\
\text { Actions }\end{array}$ & Subcases & $\begin{array}{l}\text { Additional } \\
\text { Conditions }\end{array}$ \\
\hline $\begin{array}{c}\text { No } \\
\text { Intervention }\end{array}$ & $C_{F} \leq 0$ & $\begin{array}{l}\text { The tailing } \\
\text { deposit does not } \\
\text { require } \\
\text { intervention, } \\
\text { regardless of the } \\
\text { soil composition. }\end{array}$ & None & None & None \\
\hline \multirow{2}{*}{$\begin{array}{l}\text { Conditional } \\
\text { Intervention }\end{array}$} & \multirow{2}{*}{$0<C_{F}<100$} & \multirow{2}{*}{$\begin{array}{l}\text { The tailing } \\
\text { deposit may or } \\
\text { may not require } \\
\text { intervention, this } \\
\text { depends on the } \\
\text { soil composition. }\end{array}$} & \multirow{2}{*}{$\begin{array}{l}\text { Determine } \\
\text { the clay } \\
\text { percentage } \\
x_{A} \text {. }\end{array}$} & $\begin{array}{l}\text { Intervention not } \\
\text { required, it is not } \\
\text { necessary } \\
\text { intervene the soil } \\
\text { because it is under } \\
\text { the intervention } \\
\text { value specified for } \\
\text { this type of soil. }\end{array}$ & $x_{A}>C_{F}$ \\
\hline & & & & $\begin{array}{l}\text { Intervention } \\
\text { required, the soil } \\
\text { must be intervened } \\
\text { because it exceeds } \\
\text { or equals the } \\
\text { intervention value } \\
\text { specified for this } \\
\text { type of soil. }\end{array}$ & $x_{A} \leq C_{F}$ \\
\hline $\begin{array}{l}\text { Unconditional } \\
\text { Intervention }\end{array}$ & $C_{F} \geq 100$ & $\begin{array}{l}\text { The tailing } \\
\text { deposit requires } \\
\text { intervention, } \\
\text { regardless of the } \\
\text { soil composition. }\end{array}$ & $\begin{array}{l}\text { Prepare an } \\
\text { intervention } \\
\text { plan for the } \\
\text { site. }\end{array}$ & None & None \\
\hline
\end{tabular}

2 


\section{Table 4 (on next page)}

Summary of intervention cases with respect to the adjusted threshold factor.

Each row describes a different case depending on the value of the adjusted threshold factor. 
Table 4 - Summary of intervention cases with respect to the adjusted threshold factor.

\begin{tabular}{|c|c|c|c|}
\hline Case & Condition & Priority & Required Actions \\
\hline $\begin{array}{c}\text { No Intervention } \\
\begin{array}{c}\text { Cnlikely } \\
\text { Intervention }\end{array}\end{array}$ & $A C_{F} \leq 0$ & None & None \\
\hline $\begin{array}{c}\text { Conditional } \\
\text { Intervention }\end{array}$ & $1<A C_{F}<2$ & Low & $\begin{array}{c}\text { If possible, determine the clay } \\
\text { percentage } x_{A} \text { to find if } \\
\text { intervention is required. }\end{array}$ \\
\hline $\begin{array}{c}\text { Unconditional } \\
\text { Intervention }\end{array}$ & $A C_{F} \geq 2$ & Medium & $\begin{array}{c}\text { Determine the clay percentage } x_{A} \\
\text { and find if intervention is } \\
\text { required. }\end{array}$ \\
\hline
\end{tabular}

2 


\section{Table 5 (on next page)}

Summary of results for all the studied metals.

This table presents the information regarding to the necessity of intervention results for the tailings according to the adjusted threshold factor for the different metals grouped by tailing deposit status (active, inactive or abandoned). 
Table 5 - Summary of results for all the studied metals.

\begin{tabular}{|c|c|c|c|c|c|}
\hline Element & $\begin{array}{c}\text { Deposit } \\
\text { Status }\end{array}$ & $\begin{array}{c}A C_{F} \leq 0 \\
\text { (no intervention) }\end{array}$ & $\begin{array}{l}0<A C_{F}<2 \\
\text { (conditional } \\
\text { intervention) }\end{array}$ & $\begin{array}{c}A C_{F} \geq 2 \\
\text { (unconditional } \\
\text { intervention) }\end{array}$ & Total \\
\hline \multirow{3}{*}{ As } & Active & 10 & 1 & 0 & 11 \\
\hline & Inactive & 18 & 0 & 4 & 22 \\
\hline & Abandoned & 48 & 0 & 0 & 48 \\
\hline \multirow{3}{*}{$\mathrm{Cd}$} & Active & 9 & 2 & 0 & 11 \\
\hline & Inactive & 10 & 12 & 0 & 22 \\
\hline & Abandoned & 30 & 18 & 0 & 48 \\
\hline \multirow{3}{*}{$\mathrm{Pb}$} & Active & 11 & 0 & 0 & 11 \\
\hline & Inactive & 18 & 4 & 0 & 22 \\
\hline & Abandoned & 48 & 0 & 0 & 48 \\
\hline \multirow{3}{*}{$\mathrm{Ni}$} & Active & 0 & 11 & 0 & 11 \\
\hline & Inactive & 0 & 22 & 0 & 22 \\
\hline & Abandoned & 0 & 48 & 0 & 48 \\
\hline \multirow{3}{*}{$\mathrm{Hg}$} & Active & 10 & 1 & 0 & 11 \\
\hline & Inactive & 20 & 2 & 0 & 22 \\
\hline & Abandoned & 39 & 8 & 1 & 48 \\
\hline \multirow{3}{*}{$\mathrm{Cu}$} & Active & 0 & 2 & 9 & 11 \\
\hline & Inactive & 0 & 6 & 16 & 22 \\
\hline & Abandoned & 1 & 8 & 39 & 48 \\
\hline \multirow{3}{*}{$\mathrm{Zn}$} & Active & 10 & 1 & 0 & 11 \\
\hline & Inactive & 18 & 4 & 0 & 22 \\
\hline & Abandoned & 48 & 0 & 0 & 48 \\
\hline \multirow{3}{*}{$\mathrm{Cr}$} & Active & 1 & 10 & 0 & 11 \\
\hline & Inactive & 6 & 10 & 6 & 22 \\
\hline & Abandoned & 13 & 35 & 0 & 48 \\
\hline \multicolumn{5}{|c|}{ Total } & 648 \\
\hline
\end{tabular}

2 


\section{Table 6(on next page)}

Summary of results by sample for ACTIVE deposits ("NO": no intervention, "YES": unconditional intervention and "CND": conditional intervention).

Each row corresponds to a tailing sample from active deposits, the columns show if this sampling suggests a conditional intervention, an unconditional intervention or no intervention according to the adjusted threshold factor. 
1 Table 6-Summary of results by sample for ACTIVE and INACTIVE deposits ("NO”: no

2 intervention, "YES": unconditional intervention and "CND”: conditional intervention).

\begin{tabular}{|c|c|c|c|c|c|c|c|c|c|}
\hline Deposit status & $I D$ & $\mathrm{Cr}$ & $Z n$ & $\mathrm{Ni}$ & $P b$ & $\mathrm{Hg}$ & $C u$ & $C d$ & $A s$ \\
\hline \multirow{11}{*}{ ACTIVE } & 148-TP & CND & $\mathrm{NO}$ & CND & $\mathrm{NO}$ & $\mathrm{NO}$ & CND & CND & $\mathrm{NO}$ \\
\hline & $149-W$ & $\mathrm{CND}$ & $\mathrm{NO}$ & CND & $\mathrm{NO}$ & $\mathrm{NO}$ & YES & $\mathrm{NO}$ & $\mathrm{NO}$ \\
\hline & $150-\mathrm{S}$ & CND & $\mathrm{NO}$ & CND & $\mathrm{NO}$ & $\mathrm{NO}$ & YES & $\mathrm{NO}$ & $\mathrm{NO}$ \\
\hline & $151-\mathrm{W}$ & $\mathrm{NO}$ & $\mathrm{NO}$ & $\mathrm{CND}$ & $\mathrm{NO}$ & $\mathrm{NO}$ & YES & $\mathrm{NO}$ & $\mathrm{NO}$ \\
\hline & 152-TP & CND & $\mathrm{NO}$ & CND & $\mathrm{NO}$ & $\mathrm{NO}$ & YES & CND & CND \\
\hline & $153-W$ & $\mathrm{CND}$ & $\mathrm{NO}$ & $\mathrm{CND}$ & $\mathrm{NO}$ & $\mathrm{NO}$ & YES & $\mathrm{NO}$ & $\mathrm{NO}$ \\
\hline & $154-\mathrm{S}$ & CND & $\mathrm{CND}$ & CND & $\mathrm{NO}$ & CND & YES & $\mathrm{NO}$ & $\mathrm{NO}$ \\
\hline & 155-TP & CND & $\mathrm{NO}$ & CND & $\mathrm{NO}$ & $\mathrm{NO}$ & CND & $\mathrm{NO}$ & $\mathrm{NO}$ \\
\hline & $156-\mathrm{W}$ & CND & $\mathrm{NO}$ & CND & $\mathrm{NO}$ & $\mathrm{NO}$ & YES & $\mathrm{NO}$ & $\mathrm{NO}$ \\
\hline & 692-TP & CND & $\mathrm{NO}$ & CND & $\mathrm{NO}$ & $\mathrm{NO}$ & YES & $\mathrm{NO}$ & $\mathrm{NO}$ \\
\hline & 693-TP & CND & $\mathrm{NO}$ & CND & $\mathrm{NO}$ & $\mathrm{NO}$ & YES & $\mathrm{NO}$ & $\mathrm{NO}$ \\
\hline \multirow{22}{*}{ INACTIVE } & 176-TP & CND & $\mathrm{NO}$ & CND & $\mathrm{NO}$ & CND & YES & CND & $\mathrm{NO}$ \\
\hline & 176-TP-2 & $\mathrm{CND}$ & $\mathrm{NO}$ & $\mathrm{CND}$ & $\mathrm{NO}$ & CND & YES & CND & $\mathrm{NO}$ \\
\hline & $177-W$ & CND & $\mathrm{NO}$ & CND & $\mathrm{NO}$ & $\mathrm{NO}$ & YES & CND & $\mathrm{NO}$ \\
\hline & $177-W-2$ & CND & $\mathrm{NO}$ & CND & $\mathrm{NO}$ & $\mathrm{NO}$ & YES & CND & $\mathrm{NO}$ \\
\hline & $178-\mathrm{S}$ & CND & $\mathrm{NO}$ & CND & $\mathrm{NO}$ & $\mathrm{NO}$ & YES & NO & $\mathrm{NO}$ \\
\hline & $178-S-2$ & CND & $\mathrm{NO}$ & CND & $\mathrm{NO}$ & $\mathrm{NO}$ & YES & $\mathrm{NO}$ & $\mathrm{NO}$ \\
\hline & 179-W & YES & $\mathrm{NO}$ & CND & $\mathrm{NO}$ & $\mathrm{NO}$ & CND & $\mathrm{NO}$ & $\mathrm{NO}$ \\
\hline & 179-W-2 & YES & $\mathrm{NO}$ & CND & $\mathrm{NO}$ & $\mathrm{NO}$ & CND & $\mathrm{NO}$ & $\mathrm{NO}$ \\
\hline & 180-TP & $\mathrm{NO}$ & $\mathrm{NO}$ & CND & $\mathrm{NO}$ & $\mathrm{NO}$ & YES & CND & $\mathrm{NO}$ \\
\hline & 180-TP-2 & $\mathrm{NO}$ & $\mathrm{NO}$ & CND & $\mathrm{NO}$ & $\mathrm{NO}$ & YES & CND & $\mathrm{NO}$ \\
\hline & $181-W$ & CND & $\mathrm{NO}$ & CND & $\mathrm{NO}$ & $\mathrm{NO}$ & YES & $\mathrm{NO}$ & $\mathrm{NO}$ \\
\hline & $181-W-2$ & CND & $\mathrm{NO}$ & $\mathrm{CND}$ & $\mathrm{NO}$ & $\mathrm{NO}$ & YES & $\mathrm{NO}$ & $\mathrm{NO}$ \\
\hline & 188-TP & $\mathrm{NO}$ & $\mathrm{NO}$ & CND & $\mathrm{NO}$ & $\mathrm{NO}$ & CND & $\mathrm{NO}$ & $\mathrm{NO}$ \\
\hline & 188-TP-2 & $\mathrm{NO}$ & $\mathrm{NO}$ & CND & $\mathrm{NO}$ & $\mathrm{NO}$ & CND & $\mathrm{NO}$ & $\mathrm{NO}$ \\
\hline & 189-W & YES & $\mathrm{NO}$ & CND & $\mathrm{NO}$ & $\mathrm{NO}$ & YES & CND & $\mathrm{NO}$ \\
\hline & $189-W-2$ & YES & $\mathrm{NO}$ & CND & $\mathrm{NO}$ & $\mathrm{NO}$ & YES & CND & $\mathrm{NO}$ \\
\hline & 190-TP & CND & $\mathrm{CND}$ & CND & CND & $\mathrm{NO}$ & YES & CND & YES \\
\hline & 190-TP-2 & CND & CND & CND & $\mathrm{CND}$ & $\mathrm{NO}$ & YES & CND & YES \\
\hline & $191-W$ & $\mathrm{NO}$ & CND & CND & $\mathrm{CND}$ & $\mathrm{NO}$ & CND & $\mathrm{NO}$ & YES \\
\hline & $191-W-2$ & $\mathrm{NO}$ & CND & CND & CND & $\mathrm{NO}$ & CND & $\mathrm{NO}$ & YES \\
\hline & 192-S & YES & $\mathrm{NO}$ & CND & $\mathrm{NO}$ & $\mathrm{NO}$ & YES & CND & $\mathrm{NO}$ \\
\hline & 192-S-2 & YES & $\mathrm{NO}$ & CND & $\mathrm{NO}$ & $\mathrm{NO}$ & YES & CND & $\mathrm{NO}$ \\
\hline
\end{tabular}




\section{Table 7 (on next page)}

Summary of results by sample for ABANDONED deposits ("NO": no intervention, "YES": unconditional intervention and "CND": conditional intervention).

Each row corresponds to a tailing sample from abandoned deposits, the columns show if this sampling suggests a conditional intervention, an unconditional intervention or no intervention according to the adjusted threshold factor. 
1 Table 7 -Summary of results by sample for ABANDONED deposits ("NO": no intervention,

"YES": unconditional intervention and "CND”: conditional intervention).

\begin{tabular}{|c|c|c|c|c|c|c|c|c|}
\hline$I D$ & $C r$ & $Z n$ & $\mathrm{Ni}$ & $P b$ & $\mathrm{Hg}$ & $C u$ & $C d$ & $A s$ \\
\hline $173-S$ & CND & $\mathrm{NO}$ & CND & $\mathrm{NO}$ & $\mathrm{NO}$ & CND & CND & $\mathrm{NO}$ \\
\hline $173-S-2$ & CND & $\mathrm{NO}$ & CND & $\mathrm{NO}$ & $\mathrm{NO}$ & CND & CND & $\mathrm{NO}$ \\
\hline 174-TP & CND & $\mathrm{NO}$ & CND & $\mathrm{NO}$ & $\mathrm{NO}$ & YES & $\mathrm{NO}$ & $\mathrm{NO}$ \\
\hline 174-TP-2 & CND & $\mathrm{NO}$ & CND & $\mathrm{NO}$ & $\mathrm{NO}$ & YES & $\mathrm{NO}$ & $\mathrm{NO}$ \\
\hline $175-W$ & CND & $\mathrm{NO}$ & CND & $\mathrm{NO}$ & CND & YES & $\mathrm{NO}$ & $\mathrm{NO}$ \\
\hline $175-W-2$ & CND & $\mathrm{NO}$ & CND & $\mathrm{NO}$ & CND & YES & $\mathrm{NO}$ & $\mathrm{NO}$ \\
\hline 182-TP & $\mathrm{NO}$ & $\mathrm{NO}$ & CND & $\mathrm{NO}$ & CND & YES & CND & $\mathrm{NO}$ \\
\hline 182-TP-2 & $\mathrm{NO}$ & $\mathrm{NO}$ & CND & $\mathrm{NO}$ & CND & YES & CND & $\mathrm{NO}$ \\
\hline 183-TP & NO & NO & CND & NO & $\mathrm{NO}$ & YES & NO & $\mathrm{NO}$ \\
\hline 183-TP-2 & $\mathrm{NO}$ & $\mathrm{NO}$ & CND & $\mathrm{NO}$ & $\mathrm{NO}$ & YES & $\mathrm{NO}$ & $\mathrm{NO}$ \\
\hline 184-TP & $\mathrm{NO}$ & $\mathrm{NO}$ & CND & $\mathrm{NO}$ & $\mathrm{NO}$ & CND & $\mathrm{NO}$ & $\mathrm{NO}$ \\
\hline 184-TP-2 & $\mathrm{NO}$ & NO & CND & NO & $\mathrm{NO}$ & CND & NO & $\mathrm{NO}$ \\
\hline $185-\mathrm{S}$ & $\mathrm{NO}$ & $\mathrm{NO}$ & CND & $\mathrm{NO}$ & $\mathrm{NO}$ & YES & $\mathrm{NO}$ & $\mathrm{NO}$ \\
\hline $185-\mathrm{S}-2$ & $\mathrm{NO}$ & $\mathrm{NO}$ & CND & $\mathrm{NO}$ & $\mathrm{NO}$ & YES & $\mathrm{NO}$ & $\mathrm{NO}$ \\
\hline 186-TP & CND & NO & CND & NO & $\mathrm{NO}$ & YES & CND & NO \\
\hline 186-TP-2 & CND & NO & CND & $\mathrm{NO}$ & $\mathrm{NO}$ & YES & CND & $\mathrm{NO}$ \\
\hline $187-\mathrm{S}$ & CND & $\mathrm{NO}$ & CND & NO & $\mathrm{NO}$ & YES & $\mathrm{NO}$ & $\mathrm{NO}$ \\
\hline 187-S-2 & CND & NO & CND & NO & NO & YES & NO & NO \\
\hline 193-TP & CND & NO & CND & NO & SÍ & YES & $\mathrm{NO}$ & $\mathrm{NO}$ \\
\hline 194-W & $\mathrm{NO}$ & NO & CND & NO & $\mathrm{NO}$ & YES & CND & $\mathrm{NO}$ \\
\hline 195-S & CND & $\mathrm{NO}$ & CND & $\mathrm{NO}$ & $\mathrm{NO}$ & YES & $\mathrm{NO}$ & $\mathrm{NO}$ \\
\hline 196-ТP & $\mathrm{NO}$ & $\mathrm{NO}$ & CND & $\mathrm{NO}$ & $\mathrm{NO}$ & YES & $\mathrm{NO}$ & $\mathrm{NO}$ \\
\hline $197-W$ & $\mathrm{NO}$ & $\mathrm{NO}$ & CND & NO & CND & YES & CND & $\mathrm{NO}$ \\
\hline 198-W & CND & NO & CND & $\mathrm{NO}$ & CND & YES & $\mathrm{NO}$ & $\mathrm{NO}$ \\
\hline 199-ТP & CND & $\mathrm{NO}$ & CND & $\mathrm{NO}$ & $\mathrm{NO}$ & YES & CND & $\mathrm{NO}$ \\
\hline $200-W$ & $\mathrm{CND}$ & NO & CND & $\mathrm{NO}$ & $\mathrm{NO}$ & YES & CND & $\mathrm{NO}$ \\
\hline 201-W & CND & NO & CND & NO & NO & YES & NO & $\mathrm{NO}$ \\
\hline 202-TP & $\mathrm{NO}$ & $\mathrm{NO}$ & CND & $\mathrm{NO}$ & $\mathrm{NO}$ & YES & $\mathrm{NO}$ & $\mathrm{NO}$ \\
\hline 203-S & CND & $\mathrm{NO}$ & CND & $\mathrm{NO}$ & $\mathrm{NO}$ & YES & NO & $\mathrm{NO}$ \\
\hline 204-S & CND & $\mathrm{NO}$ & CND & NO & $\mathrm{NO}$ & YES & CND & $\mathrm{NO}$ \\
\hline $205-\mathrm{S}$ & CND & NO & CND & NO & NO & YES & NO & $\mathrm{NO}$ \\
\hline 206-S & CND & $\mathrm{NO}$ & CND & $\mathrm{NO}$ & $\mathrm{NO}$ & YES & CND & $\mathrm{NO}$ \\
\hline $207-W$ & CND & $\mathrm{NO}$ & CND & NO & $\mathrm{NO}$ & CND & $\mathrm{NO}$ & $\mathrm{NO}$ \\
\hline 208-ТP & CND & $\mathrm{NO}$ & CND & $\mathrm{NO}$ & $\mathrm{NO}$ & $\mathrm{NO}$ & $\mathrm{NO}$ & $\mathrm{NO}$ \\
\hline 209-ТP & CND & $\mathrm{NO}$ & CND & NO & CND & YES & CND & $\mathrm{NO}$ \\
\hline $210-\mathrm{W}$ & CND & $\mathrm{NO}$ & CND & $\mathrm{NO}$ & $\mathrm{NO}$ & YES & CND & $\mathrm{NO}$ \\
\hline $211-W$ & CND & $\mathrm{NO}$ & CND & $\mathrm{NO}$ & CND & YES & $\mathrm{NO}$ & $\mathrm{NO}$ \\
\hline 212-TP & CND & $\mathrm{NO}$ & CND & NO & NO & YES & $\mathrm{NO}$ & $\mathrm{NO}$ \\
\hline $213-\mathrm{S}$ & CND & $\mathrm{NO}$ & CND & NO & NO & YES & CND & $\mathrm{NO}$ \\
\hline 214-TP & CND & $\mathrm{NO}$ & CND & $\mathrm{NO}$ & $\mathrm{NO}$ & CND & CND & $\mathrm{NO}$ \\
\hline $215-\mathrm{W}$ & CND & NO & CND & NO & NO & CND & NO & $\mathrm{NO}$ \\
\hline $216-\mathrm{S}$ & CND & $\mathrm{NO}$ & CND & $\mathrm{NO}$ & NO & YES & $\mathrm{NO}$ & $\mathrm{NO}$ \\
\hline 217-TP & $\mathrm{NO}$ & $\mathrm{NO}$ & CND & NO & NO & CND & NO & $\mathrm{NO}$ \\
\hline $218-\mathrm{W}$ & CND & $\mathrm{NO}$ & CND & $\mathrm{NO}$ & $\mathrm{NO}$ & YES & $\mathrm{NO}$ & $\mathrm{NO}$ \\
\hline 219-ТP & CND & $\mathrm{NO}$ & CND & $\mathrm{NO}$ & NO & YES & CND & $\mathrm{NO}$ \\
\hline $220-\mathrm{W}$ & CND & NO & CND & $\mathrm{NO}$ & NO & YES & NO & $\mathrm{NO}$ \\
\hline $221-\mathrm{S}$ & CND & $\mathrm{NO}$ & CND & $\mathrm{NO}$ & $\mathrm{NO}$ & YES & $\mathrm{NO}$ & $\mathrm{NO}$ \\
\hline $222-\mathrm{S}$ & CND & NO & CND & NO & NO & YES & CND & NO \\
\hline
\end{tabular}




\section{Table 8 (on next page)}

Assigned weights to each element for the calculation of the Weighted Intervention Ranking.

Each row in this table shows an element with its respective weight for the calculation of the Weighted Intervention Ranking. 
1 Table 8-Assigned weights to each element for the calculation of the Weighted Intervention

2 Ranking.

\begin{tabular}{|c|c|}
\hline Element & Assigned Weight \\
\hline $\mathrm{Cr}$ & 2.0 \\
\hline $\mathrm{Zn}$ & 1.0 \\
\hline $\mathrm{Ni}$ & 3.0 \\
\hline $\mathrm{Pb}$ & 3.0 \\
\hline $\mathrm{Hg}$ & 2.0 \\
\hline $\mathrm{Cu}$ & 1.0 \\
\hline $\mathrm{Cd}$ & 3.0 \\
\hline $\mathrm{As}$ & 3.0 \\
\hline
\end{tabular}

3 


\section{Table 9 (on next page)}

Summary of results for the top ten critical sites according to their WIR value.

Each row represents a tailing sample, this table details the values of the adjusted threshold factor for each element and the value of the WIR, it also includes the information about the deposit from where the sample was extracted. 
1 Table 9 -Summary of results for the top ten critical sites according to their WIR value.

\begin{tabular}{|c|c|c|c|c|c|c|c|c|c|c|c|}
\hline ID & Deposit & Status & $\mathbf{A s}$ & $\mathbf{C d}$ & $\mathbf{P b}$ & $\mathbf{N i}$ & $\mathbf{H g}$ & $\mathbf{C u}$ & $\mathbf{Z n}$ & $\mathbf{C r}$ & $\mathbf{W I R}$ \\
\hline $190-\mathrm{TP}-2$ & ARIZONA 1 & INACTIVE & 2.45 & 0.84 & 1.21 & 1.27 & -1.73 & 2.02 & 1.26 & 1.39 & 19.88 \\
\hline $190-\mathrm{TP}$ & ARIZONA 1 & INACTIVE & 2.45 & 0.59 & 1.21 & 1.27 & -1.73 & 2.02 & 1.26 & 1.39 & 19.13 \\
\hline $191-\mathrm{W}-2$ & ARIZONA 2 & INACTIVE & 2.74 & -0.27 & 1.68 & 1.19 & -1.44 & 1.86 & 1.56 & -0.36 & 15.84 \\
\hline $191-\mathrm{W}$ & ARIZONA 2 & INACTIVE & 2.74 & -0.57 & 1.68 & 1.19 & -1.44 & 1.86 & 1.56 & -0.36 & 14.93 \\
\hline $152-\mathrm{TP}$ & SERENA & ACTVE & 1.58 & 1.19 & -1.12 & 1.17 & -1.78 & 2.97 & -0.94 & 1.18 & 9.27 \\
\hline $176-\mathrm{TP}-2$ & ARENILLAS 2 & INACTIVE & -1.33 & 0.84 & -1.67 & 1.23 & 1.73 & 2.97 & -1.18 & 1.14 & 4.71 \\
\hline $176-\mathrm{TP}$ & ARENILLAS 2 & INACTIVE & -1.33 & 0.75 & -1.67 & 1.23 & 1.73 & 2.97 & -1.18 & 1.14 & 4.45 \\
\hline $197-\mathrm{W}$ & PUNTA & ABANDONE & -1.33 & 1.62 & -1.62 & 1.16 & 1.82 & 2.61 & -1.00 & -0.22 & 4.30 \\
\hline $209-\mathrm{DP}$ & IRENE 2 & $\begin{array}{c}\text { ABANDONE } \\
\text { D }\end{array}$ & -1.33 & 1.19 & -1.58 & 1.18 & 0.97 & 2.87 & -0.97 & 0.69 & 3.57 \\
\hline $189-\mathrm{W}-2$ & ARIZONA 1 & INACTIVE & -1.33 & -1.09 & -1.54 & 1.21 & 2.12 & 2.99 & -0.99 & 1.08 & 3.14 \\
\hline
\end{tabular}

2

3 